\title{
Using fuzzy cognitive maps to describe current system dynamics and develop land cover scenarios: a case study in the Brazilian Amazon
}

\author{
Luciana S. Soler ${ }^{\mathrm{a} *}, \mathrm{Kasper}_{K^{\mathrm{b}}}^{\mathrm{b}}$, Gilberto Camara ${ }^{\mathrm{a}}$ and Antoine Veldkamp ${ }^{\mathrm{c}}$ \\ ${ }^{a}$ Earth System Centre, National Institute for Space Research (INPE), São José dos Campos, São \\ Paulo, Brazil; ${ }^{b}$ Department of Environmental Sciences, Wageningen University, Wageningen, The \\ Netherlands; ${ }^{c}$ Faculty of Geo-Information Science and Earth Observation (ITC), University of \\ Twente, Enschede, The Netherlands
}

(Received 14 February 2010; final version received 18 November 2010)

\begin{abstract}
In this study we developed a methodology to identify and quantify the relationships among determinants of land cover change using a regional case study in the Brazilian Amazon. The method is based on the application of fuzzy cognitive maps (FCMs), a semi-quantitative tool that provides a structured assessment of key feedbacks in scenario analysis. Novel to the application of FCMs is the use of spatial data-sets as the main input to build a cognitive map. Identification of interactions between land cover determinants and strengths is based on an empirical analysis of spatially explicit data and literature review. Expert knowledge is adopted to identify the strengths and weaknesses of the method. Potential pitfalls, such as spatial autocorrelation and scale issues, identified are intrinsic to the empirical data analysis. The outputs of the resulting FCMs are compared to the outputs of spatially explicit models under similar scenarios of change. The proposed method is said to be robust and reproducible when compared with participatory approaches, and it can endorse the consistency between demand and allocation in scenario analysis to be used in spatially explicit models.
\end{abstract}

Keywords: fuzzy cognitive maps; land cover change; interactions; scenarios; deforestation; Brazilian Amazon

\section{Introduction}

The comprehension of coupled human-environment systems has been recognized as an important issue by the land science community (Turner II, Moran, and Rindfuss 2004; Liu et al. 2007). This is particularly relevant in the context of the Brazilian Amazon, an enormous and heterogeneous region regarding social, economic and environmental factors (Perz and Walker 2002; Becker 2004; Alves 2008; Fearnside 2008b). The multi-causality of land use and land cover dynamics required new approaches combining generic biophysical and socio-economic data as well as human-environment conditions specific to case studies (Lambin et al. 2001). As a result, a number of land change studies have moved from relatively simplistic representations with a few driving forces to a more complex multi-variable understanding (Câmara et al. 2005; Geist et al. 2006).

Tackling the complexity of land cover change requires investigation of interactions among factors at different spatial and temporal scales (Veldkamp and Fresco 1996; Lambin

\footnotetext{
*Corresponding author. Email: 1soler@dpi.inpe.br
} 
and Geist 2003). These interactions include feedback mechanisms that are key steps to comprehend non-linear landscape processes and their links to human decision-making (Claessens, Schoorl, Verburg, Geraedts, and Veldkamp 2009). However, inherent limitations of land use/land cover change frameworks to incorporate feedback mechanisms between human actions and environmental changes are still a challenge to modellers that use spatially explicit approaches (Veldkamp and Verburg 2004; Verburg 2006; Verburg, Kok, Pontius, and Veldkamp 2006; Parker, Hessl, and Davis 2008).

The implementation of feedback mechanisms has a number of constraints in both spatially explicit and agent-based models. Data availability and computational complexity are some of the limitations when linking spatial variation of land use to the social structure of decision-making (Verburg 2006). Although multi-agent models can combine cellular- and agent-based concepts in an integrated approach, many challenges such as modelling the behaviour of various agents and institutions remain, taking into account the complexity of time and spatial scales in a given land use system (Parker, Manson, Janssen, Hoffmann, and Deadman 2003).

Recent studies have indicated the potential of fuzzy cognitive mapping as a proxy tool to investigate the role of feedback mechanisms in coupled human-environment systems. Cognitive maps have been useful in analysing decision-making and complex social systems (Roberts 1973; Axelrod 1976; Montazemi and Conrath 1986; Carley and Palmquist 1992; Cossette and Audet 1992). Kosko (1986) was the first to associate cognitive maps to fuzzy logic by incorporating qualitative knowledge as fuzzy causal functions using a matrix representation. Thus, a fuzzy cognitive map (FCM) is a cognitive map where relationships among the elements derive from a given mental map, with their relative importance representing the magnitude of the causality of such elements. In this context, a FCM can play an important role in building semi-quantitative scenarios taking into account different stakeholders' perceptions (Kok 2009; Vliet, Kok, and Veldkamp 2010).

Application of FCMs to land use science requires the interpretation of subjective information, for example, stakeholders' perceptions or expert knowledge, into semi-quantitative description of variables and their interrelations (Ozesmi, U. and Ozesmi, S. 2003; Kok 2009; Vliet et al. 2010). Although the semi-quantitative nature of FCMs is considered a weak point when linking them to quantitative models, the dynamic outputs of FCMs in scenario development can facilitate land use/land cover models by unveiling hidden feedback mechanisms as shown by Kok (2009). Most land use/land cover change models use an external demand based on an economic approach of a trend extrapolation, usually yielding a very static and almost gradual change in demand (Milne, Aspinall, and Veldkamp 2009). In reality, demand changes rather erratically due to all kinds of feedbacks in land use systems. These feedbacks can be represented in an FCM allowing a semi-quantified evaluation of their role in specific demand scenarios.

In summary, considering the state of the art of current applications of FCMs in environmental sciences, we identify two aspects that have not received much attention in literature and are essential to explore further:

(1) FCMs are often constructed during stakeholder workshops and therefore represent the (subjective) opinion of a small group of individuals. A more objective and therefore reproducible method does not exist.

(2) FCMs are not linked to quantitative models, even though their semi-dynamic character provides possibilities to do so. 
Taking into account these two aspects, this article addresses a new method to develop FCMs. The main objective is to present and test a reproducible and robust method to develop FCMs based on spatially explicit data in combination with the existing literature. The resulting FCM is compared to an FCM constructed directly by a number of experts from leading institutes on spatial research in Brazil. Both products are compared to evaluate strong and weak points of the proposed new method of building FCMs. To address the second aspect, we illustrate how FCMs can be converted to land cover change scenarios.

\section{FCMs in land use science}

A FCM is a collection of concepts $C_{i}$ that in land use science can represent the land use types and their determinants of change. These concepts are linked to each other by causal relationships represented by arrows $\left(C_{i} \rightarrow C_{i+1}\right)$, as illustrated in Figure 1. Each concept receives an initial value $a \in[-1,1]$ that is transferred in the first step of the FCM calculation to another concept through the relationship between them. In addition, each relationship is quantified by a weight, varying between 0 and 1 , which is the strength of the relationship between the two given concepts (Kosko 1986).

The set of initial values of all concepts form a matrix $1 \times n$ called state vector, where $n$ is the total number of concepts adopted. In addition, the causal relationships can also be represented by an $n \times n$ matrix called adjacency matrix, where the position and magnitude of each $C_{i, j}$ element indicate, respectively, the direction of the causality and the weights between the concepts $\left(C_{i} \stackrel{\text { weight }}{\longrightarrow} C_{j}\right.$ ). The iterations in a FCM consist of multiplying the state vector by the adjacency matrix obtaining a new state vector. This step is then repeated until there is a quasi stabilization of the changes in the state vector. The new state vector can assume values outside the interval between -1 and 1 . In the example of Figure 1, the initial state vector is $A=\left[\begin{array}{lll}1 & 0.5 & -0.5\end{array}\right]$ and after the first iteration it becomes $A=\left[\begin{array}{lll}0.2 & 0.5 & 1\end{array}\right]$. Once the values of elements in the state vector and in the adjacency matrix are defined, the iterations in a FCM can be implemented in different statistical packages, such as R-project and Microsoft Office Excel ${ }^{\text {B }}$ software, which were used in this study (Microsoft Corporation 2003; R-project 2010). For further methodological details of FCMs, refer to Kok (2009).

When applying FCM to land use science, the stakeholders' perceptions and expert knowledge can be considered a strong point of the tool because of its flexibility in including the consensual opinion of any group during a short workshop. However, to link FCMs to spatially explicit models of land use/land cover change, a larger degree of objectivity is desired, which is attempted by the proposed method that links spatial data to FCMs described in the next section.

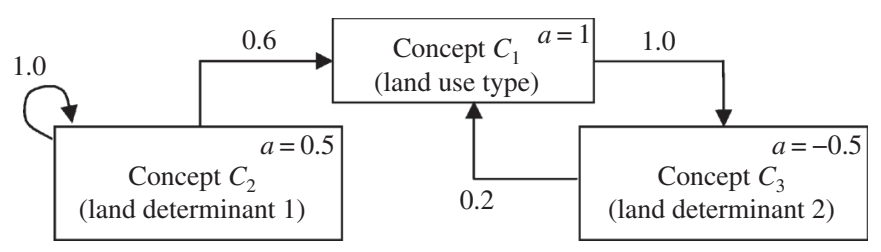

Figure 1. Graphical representation of concepts (with state values $a$ ), their causal relationships and weights indicated by arrows in a fuzzy cognitive map. 


\section{Linking FCMs to spatially explicit data}

The proposed methodology is illustrated in Figure 2 and comprises six steps: (1) selection of land cover change determinants based on literature review and fieldwork information; (2) codification of spatial data representing potential land cover change determinants (or their proxies); (3) cross-analysis between significant correlation coefficients of coded variables and literature review; (4) establishment of causal relationships based on literature review; (5) semi-quantification of causal relationships based on the correlation coefficients; and (6) building and calibrating the obtained FCM, which is the central object of the method and is called data-FCM.

\subsection{Selection of land cover change determinants}

Located at the southwest part of the Brazilian Amazon, the study area encloses the northeast of Rondônia State (Figure 3). It is characterized by small landholders $(<200 \mathrm{ha})$ based in official settlements established from the 1970s until recent years (Browder 1994; Machado 1998; INCRA 2008). Most of the old settlements (established before the 1980s) are located along the main road BR-364 on more fertile soils, whereas the ones established after the 1980s are located in poorer soils along secondary roads (Fearnside 1986; Machado 1998). Accessibility is an important driver for small farmers who intensify land use in more accessible areas (Alves, Escada, Pereira, and Linhares 2003). Medium (250$1000 \mathrm{ha}$ ) and big farms (>1000 ha) occupy areas outside the official settlements, but land aggregation is often observed in older settlements (Coy 1987; Millikan 1992; Pedlowski, Dale, Matricardi, and da Silva 1997; Escada 2003).

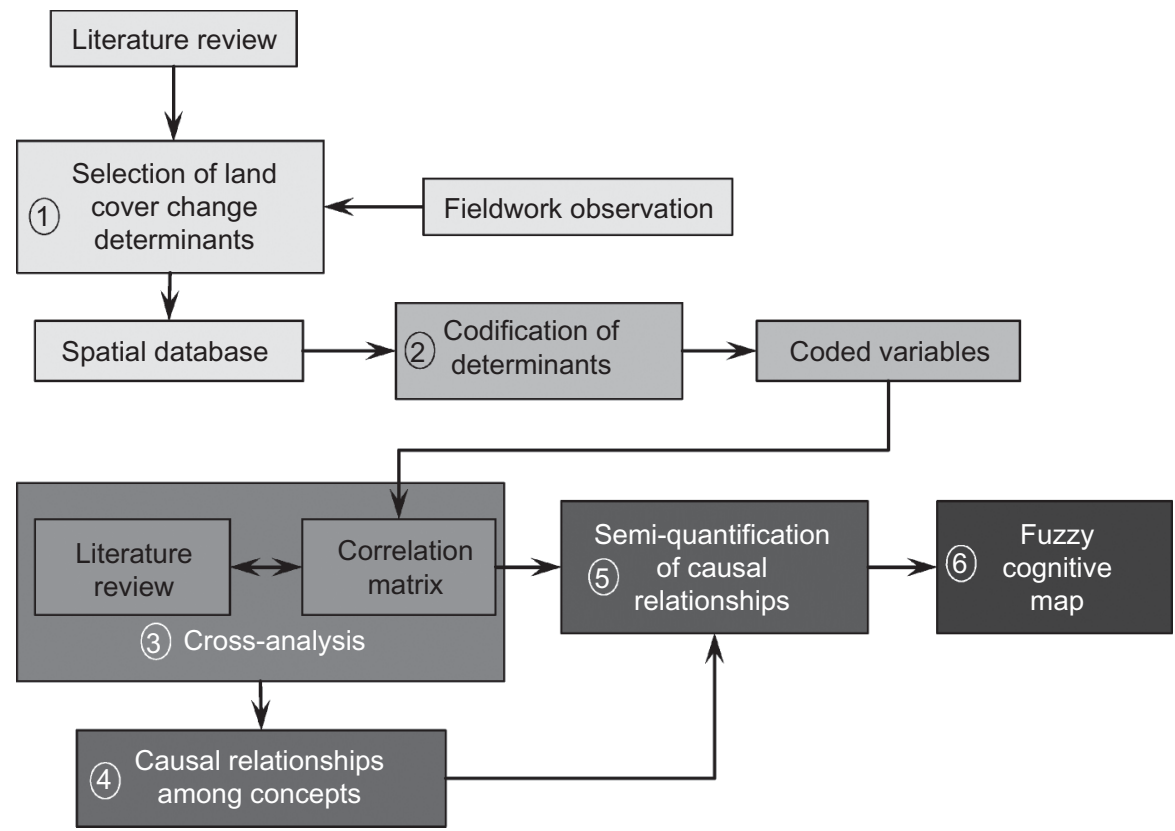

Figure 2. Flowchart of methodological steps proposed to build a fuzzy cognitive map based on spatially explicit data. The six main steps of the method are indicated by numbers. 


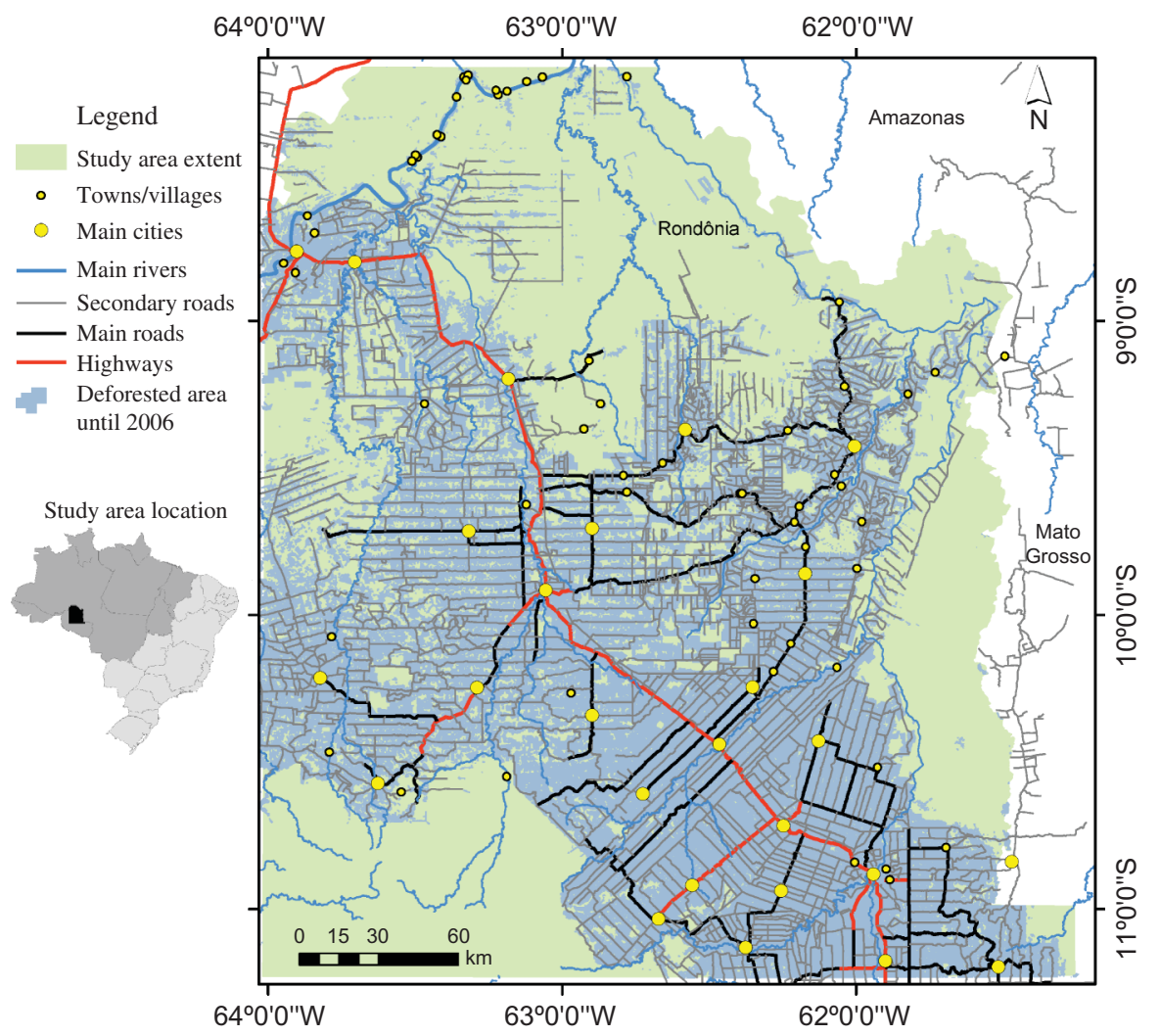

Figure 3. Study area extent indicating roads, rivers, urban areas and deforested areas.

Soil fertility is an important determinant when hardly any forest remnants are left (Roberts et al. 2002; Soler and Verburg 2010). Rainfall determines deforestation at the regional scale as more pronounced dry seasons increase agro-pasture productivity (Schneider, Arima, Veríssimo, Barreto, and Souza 2000; Sombroek 2001). Thus, areas with more consecutive dryer months are more prone to deforestation, which is directly linked to fire occurrence (Aragão et al. 2007, 2008). Furthermore, consecutive years of intense droughts can cause more fire events in the long term (Nepstad et al. 2001; Malhi et al. 2009).

Ranching is the predominant land use among medium and big farmers, but it can also be an important source of income for small landholders (Pedlowski et al. 1997; Walker, Moran, and Anselin 2000). The regional and global beef demands are pointed as the main causes driving the increase in cattle herd in the Brazilian Amazon (Faminow 1997; Arima, Barreto, and Brito 2005). Even though government subsidies have decreased in the last two decades, subsidized loans for pasture activities can still influence household level decisions (Moran 1993; Brasil 2007). In old settlements the ageing of householders affects labour force availability, which can lead to an increase of pasture area and even force small farmers to sell their land in areas progressively dominated by large farms (Browder et al. 2008). This local dynamics can explain the stronger causality between deforestation and the number of inhabitants as well as between deforestation and the per capita income rather than population density in old settlements in the northeast of Rondônia State (Soler, Escada, and Verburg 2009). 
Despite the fact that public policies have strengthened forest conservation in the Brazilian Amazon (Jenkins and Joppa 2009), forest reserves and indigenous lands are still threatened by the lack of appropriate enforcement (Fearnside 2003; Pedlowski et al. 2005). In parallel, land speculation, mining and logging markets attract land grabbers to either unclaimed or protected areas that might end up occupied by squatters. In some cases, the forest reserves' required inside properties (legal reserves) are invaded by squatters compelling the local authorities to create new settlements (Fearnside 2005). Although land tenure data are incomplete, deforestation at the fringes of old settlements on legal or forest reserves indicates informal land markets linked to illegal occupation (Fujisaka, Bell, Thomas, Hurtado, and Crawford 1996; Brandão, Souza, Ribeiro, and Sales 2007; Sills and Caviglia-Harris 2008).

From the location factors described above, the following deforestation determinants were selected: location of old and new settlements (i.e. established before and after the 1980s); accessibility to infrastructure; size of properties; cattle herd; subsidized credits; forest and indigenous reserves; land prices; number of inhabitants; age of householders; and per capita income. Further data description can be found in Table 1.

\subsection{Coding spatial data of potential land cover determinants}

The selected deforestation determinants in Rondônia State were organized in a cellular database at $250 \mathrm{~m}$ resolution. These potential land cover determinants were coded into variables (listed in Table 1) using as reference the procedure adopted by Scouvart et al. (2007). The coded variables represent the concepts to be adopted in the data-FCM.

Deforested and forested cells were extracted from land use maps from the PRODES project (INPE 2009) and coded as 1 and 0, respectively. Accessibility was calculated as the cost distance to the existing infrastructure in 2000 (urban areas, slaughterhouses, dairy industries, sawmills and mining areas), as described in Verburg, Overmars, and Witte (2004). Infrastructure data included roads, urban areas, sawmills, mining areas, slaughterhouses and dairy industries (IBGE 2000; CPRM 2004; IBAMA 2005; MAPA 2008). Based on Alves, Pereira, Sousa, Soares, and Yamaguchi (1999), infrastructure was calculated as a buffer area of $12.5 \mathrm{~km}$ from the existing infrastructure and coded as 1 or as 0 elsewhere.

The occurrence of fires in 2000 was retrieved from remote sensing products (INPE/CPTEC 2005) and assessed by the Euclidian distance to hot spots with no codification. A soil fertility map retrieved from RADAMBRASIL (1978) was coded as 1 for two classes indicating the highest fertile soils and 0 for all other classes. Following Sombroek (2001), the database cells with rainfall lower than $100 \mathrm{~mm}$ during the dry season (AprilSeptember) were considered the driest areas. Thus, dry season severity was coded as 1 when lower than this cut-off value or as 0 elsewhere.

The variables retrieved from census data as the number of inhabitants, per capita income and age of householders were not coded, to avoid considerable loss of spatial variability due to their aggregation at the district level (IBGE 2000). Also, no codification was applied to cattle herd, subsidized credits and land prices (IDARON 2006; Brasil 2007; INCRA 2007). Old and new settlements were retrieved from official colonized areas until 1980 and 2000, respectively, whereas spontaneous colonization areas were assessed subtracting areas of official settlements, conservation reserves and indigenous lands (IBAMA 2005; INCRA 2008). Each of these spatial partitions was considered a unique variable coded as 1 or as 0 elsewhere. 
Table 1. Description of variables adopted to represent the concepts in the data-FCM indicating the data source and the type of codification used.

\begin{tabular}{|c|c|c|c|}
\hline Variable name & Spatial data description & Source & Codification \\
\hline $\begin{array}{l}\text { Agro-pasture } \\
\text { expansion }\end{array}$ & $\begin{array}{l}\text { Deforested area extracted from land cover } \\
\text { map at 1:250,000 from } 1988 \text { to } 2000 \\
\text { (TM/Landsat image classification) }\end{array}$ & INPE (2009) & Binary \\
\hline $\begin{array}{l}\text { Dry season } \\
\text { severity }\end{array}$ & $\begin{array}{l}\text { Cells where precipitation was below the } \\
\text { average in the dry season }\end{array}$ & $\begin{array}{l}\text { INPE/CPTEC } \\
\text { (2005) }\end{array}$ & Binary \\
\hline Land prices & $\begin{array}{l}\text { Average of total property value per hectare } \\
\text { per municipality in Rondônia in } 2000\end{array}$ & INCRA (2007) & Continuous \\
\hline High fertility & $\begin{array}{l}\text { Areas with the most fertile soils extracted } \\
\text { from soil fertility map at scale } \\
1: 1,000,000\end{array}$ & $\begin{array}{l}\text { RADAMBRASIL } \\
\text { (1978) }\end{array}$ & Binary \\
\hline Accessibility & $\begin{array}{l}\text { Travel time through paved and unpaved } \\
\text { roads to main urban areas, } \\
\text { slaughterhouses, dairy industries, } \\
\text { sawmills and mining areas }\end{array}$ & $\begin{array}{l}\text { IBGE (2000); } \\
\text { CPRM (2004); } \\
\text { IBAMA (2005); } \\
\text { MAPA (2008) }\end{array}$ & Continuous \\
\hline Infrastructure & $\begin{array}{l}12 \mathrm{~km} \text { buffer from main infrastructure } \\
\text { (roads, urban areas, slaughterhouses, } \\
\text { dairy industries) }\end{array}$ & & Binary \\
\hline Fire spots & $\begin{array}{l}\text { Euclidian distance to fire spots (hot pixels) } \\
\text { in } 2000\end{array}$ & $\begin{array}{l}\text { INPE/CPTEC } \\
\text { (2005) }\end{array}$ & Continuous \\
\hline Forest reserves & $\begin{array}{l}\text { Areas allocated to conservation reserves } \\
\text { and indigenous lands in } 2000\end{array}$ & IBAMA (2005) & Binary \\
\hline $\begin{array}{l}\text { Subsidized } \\
\text { credits }\end{array}$ & $\begin{array}{l}\text { Credits granted to landholders and rural } \\
\text { association for either pasture or } \\
\text { agriculture activities within 1999-2000 }\end{array}$ & Brasil (2007) & Continuous \\
\hline Old settlements & $\begin{array}{l}\text { Areas allocated to official settlements } \\
\text { established within 1970-1989 and } \\
\text { within 1990-2000 }\end{array}$ & INCRA (2008) & Binary \\
\hline New settlements & & & Binary \\
\hline $\begin{array}{l}\text { Spontaneous } \\
\text { colonization }\end{array}$ & $\begin{array}{l}\text { Areas allocated outside official settlements, } \\
\text { that is, areas of spontaneous colonization }\end{array}$ & & Binary \\
\hline Cattle herd & Cattle herd per municipality in 2000 & IDARON (2006) & Continuous \\
\hline $\begin{array}{l}\text { Per capita } \\
\text { income }\end{array}$ & $\begin{array}{l}\text { Total nominal income/inhabitants per } \\
\text { census district in } 2000\end{array}$ & IBGE (2000) & Continuous \\
\hline $\begin{array}{l}\text { Number of } \\
\text { inhabitants }\end{array}$ & Inhabitants per census district for 2000 & IBGE (2000) & Continuous \\
\hline $\begin{array}{l}\text { Age of } \\
\text { householders }\end{array}$ & $\begin{array}{l}\text { Age of householders per census district in } \\
2000\end{array}$ & IBGE (2000) & Continuous \\
\hline
\end{tabular}


Table 2. Decision rules adopted in the cross-analysis between the correlation matrix of coded variables and the literature review of case studies in the Brazilian Amazon.

\begin{tabular}{lccc}
\hline & \multicolumn{2}{c}{ Significant Pearson correlation $(p>0.005)$} \\
\cline { 3 - 4 } Decision rules & Yes & No \\
\hline $\begin{array}{l}\text { Relevant to the } \\
\text { literature }\end{array}$ & No & $\begin{array}{c}\text { Explored in the sensitivity } \\
\text { analysis }\end{array}$ & $\begin{array}{c}\text { Explored in the } \\
\text { sensitivity } \\
\text { analysis } \\
\text { Not included in the } \\
\text { data-FCM }\end{array}$ \\
\hline
\end{tabular}

\subsection{Correlation values versus literature review}

The third step of the proposed methodology consisted of a cross-analysis between the coded variables, presented in a Pearson correlation matrix, and the literature review. The cross-analysis consisted of selecting the significant correlations (at 99\% confidence level two-tailed test) that were confirmed by the literature. The selected correlations indicated the relevant causal relationships among any pair of concepts.

The decision rules adopted in the cross-analysis are given in Table 2. The chosen relationships to build the data-FCM had to necessarily fulfil both conditions: to present a significant Pearson correlation and to be relevant to one or more case studies retrieved. Relationships without significant correlations and with no evidence from the literature were excluded. The literature review was limited to cases adopting spatial analysis at local or regional scale in Rondônia, or to areas presenting similar land occupation history, such as official settlements in Pará and in Acre states. Relationships occurring at broad temporal scales, such as fire reoccurrence due to intensified dry seasons, could only be

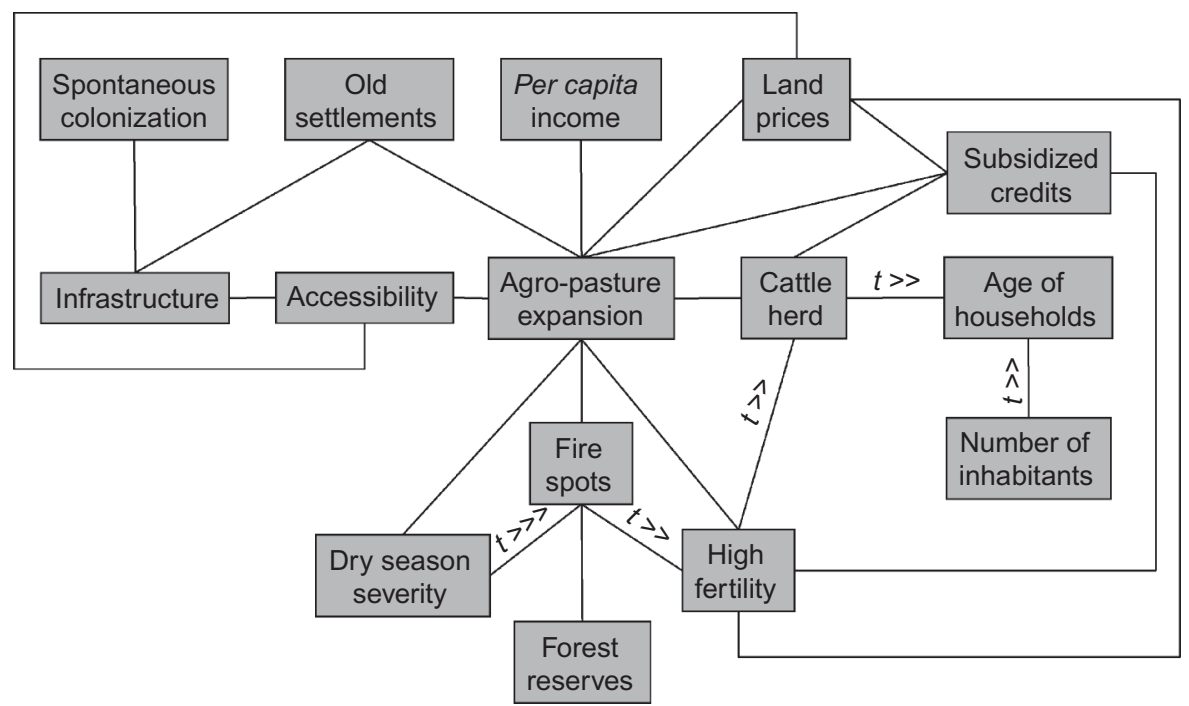

Figure 4. Relationships among concepts resulted from the cross-analysis between the Pearson correlation values and literature review of specific case studies. Relationships occurring at longer time scales are indicated by $t>>$ (demographic and landscape processes) or by $t>>>$ (climatic processes). 
confirmed by case studies at the scale of the entire Amazon (for the complete list of case studies per relationship see Appendix 1). Figure 4 illustrates the relationships selected in the cross-analysis and used to build the data-FCM.

\subsection{Causal relationships}

Once the relationships among concepts were established in a cognitive map based on spatial data, the next step was to determine their causality. The causality among relationships can take opposite directions depending on the assumptions made. As a result, the directions of the arrows necessarily have to be derived from the literature.

Road construction and deforestation is an example of disputed causality in the Brazilian Amazon. Although some authors argue that roads are the main cause of deforestation and forest fragmentation (Laurance, Albernaz, Fearnside, Vasconcelos, and Ferreira 2004; Arima, Walker, Sales, Souza, and Perz 2008), others claim that roads play a synergic role with other location factors and cause less impact when appropriate enforcement is applied (Soares-Filho et al. 2004; Câmara et al. 2005; Fearnside and Graca 2006). For the cases where the literature was inconclusive, we argue that the most recent publications applied to Rondônia at the regional scale represent the most significant insights. Table 3 indicates the directed edges (direction of the arrows) of the causal relationships identified and their supporting literature.

\subsection{Semi-quantifying relationships}

In this step the correlation matrix was used to estimate the strength of any relationship, which followed the same logic of adopting a reproducible and objective method. Similar to the method described by Kok (2009), ranking the correlation values into an interval variable $X \in[0,1]$ representing the weights, we obtained the precise numeric distance between the correlations. Two initial assumptions were made. First, no relationship received a value of 1.0, indicating that a change in none of the concepts can lead to an equally strong change of another concept. It also implies that deforestation can only be explained by a synergy of several aspects (Soares-Filho et al. 2006; Aguiar, Câmara, and Escada 2007; Soler et al. 2009). Second, no significant relationships in the correlation matrix received a value of 0.1 , assuming that relationships identified in the literature had a strength of at least 0.2.

The highest and the lowest correlation values of selected relationships received values of 0.9 and 0.2 , respectively. The correlation values in between were then classified into a number of categories matching the exact numeric distance between 0.9 and 0.2 (see Table 4). To be concise, the semi-quantification of relationships was assessed by ranking the strengths of relationships where the final weights represent the relative strengths of causality.

\subsection{Building and calibrating FCMs}

The final step consisted of bringing together the structure of the relationships (Figure 4), their causality (Table 3 ) and weights (Table 4) into a FCM in a matrix form arranging the adjacency matrix and the state vector.

The FCM is assumed to be calibrated when it reaches the quasi stabilization, that is, when the state values of all concepts become steady. Therefore, the calibration was done by varying the state values of specific concepts (from 0 to 1 ), until their stabilization after a number of iterations. In general, the concepts chosen for the state vector calibration are those that stabilize the system as a whole. Stabilization is also obtained by varying the eigenvalues in the adjacency matrix (from -1 to +1 ), which represent the self-reinforcing 
Table 3. Causal relationships among the concepts in Rondônia State with the respective case studies.

\begin{tabular}{|c|c|c|}
\hline \multicolumn{2}{|c|}{ Causal relationships assumed among concepts } & Supporting literature \\
\hline Agro-pasture expansion & $\begin{array}{l}\leftarrow+\text { Dry season severity } \\
\leftarrow+\text { Land prices } \\
\leftarrow+\text { High fertility } \\
\leftarrow+\text { Accessibility } \\
\leftarrow+\text { Old settlements } \\
\leftarrow+\text { Cattle herd } \\
\leftarrow+\text { Subsidized credits } \\
\leftarrow+\text { Per capita income }\end{array}$ & $\begin{array}{l}\text { Browder (1988), Fujisaka et al. (1996), } \\
\text { Andersen and Reis (1997), Alves et al. } \\
\text { (1999, 2003), Sombroek (2001), } \\
\text { Roberts et al. (2002), Chomitz and } \\
\text { Thomas (2003), Escada (2003), } \\
\text { Margulis (2004), Arima et al. (2005), } \\
\text { Aguiar et al. (2007), Aragão et al. } \\
\text { (2008), Browder } \text { et al. (2008), Sills } \\
\text { and Caviglia-Harris (2008), Soler et al. } \\
\text { (2009) }\end{array}$ \\
\hline Dry season severity & $\begin{array}{l}\leftarrow+\text { Fire spots } \\
\leftarrow+\text { Agro-pasture } \\
\text { expansion }\end{array}$ & $\begin{array}{l}\text { Laurance and Williamson (2001), } \\
\quad \text { Sombroek (2001), Aragão et al. (2008) }\end{array}$ \\
\hline Land prices & $\begin{array}{l}\leftarrow-\text { Agro-pasture } \\
\text { expansion }\end{array}$ & $\begin{array}{l}\text { Margulis (2004), Arima et al. (2005), } \\
\text { Sills and Caviglia-Harris (2008) }\end{array}$ \\
\hline High fertility & $\begin{array}{l}\leftarrow+\text { High fertility } \\
\leftarrow+\text { Accessibility } \\
\leftarrow+\text { Subsidized credits } \\
\leftarrow-\text { Fire spots } \\
\leftarrow+\text { Subsidized credits } \\
\leftarrow+\text { Dry season severity }\end{array}$ & $\begin{array}{l}\text { Fearnside (1986), Hughes, Kauffman, } \\
\text { and Cummings (2002), Numata et al. } \\
\text { (2003), Cochrane, T.T. and Cochrane, } \\
\text { T.A. (2006) }\end{array}$ \\
\hline Accessibility & $\begin{array}{l}\leftarrow+\text { Agro-pasture } \\
\text { expansion } \\
\leftarrow+\text { Infrastructure } \\
\leftarrow-\text { Forest reserves }\end{array}$ & $\begin{array}{l}\text { Alves et al. (1999), Pedlowski et al. } \\
\text { (2005), Soler et al. (2009), Soler and } \\
\text { Verburg (2010) }\end{array}$ \\
\hline Infrastructure & $\begin{array}{l}\leftarrow+\text { Old settlements } \\
\leftarrow+\text { Spontaneous } \\
\quad \text { colonization } \\
\leftarrow+\text { New settlements }\end{array}$ & $\begin{array}{l}\text { Alves et al. (1999), Alves (2002), } \\
\text { Brandão and Souza (2006), Brandão } \\
\text { et al. (2007), Soler et al. (2009), Soler } \\
\text { and Verburg (2010) }\end{array}$ \\
\hline Fire spots & $\begin{array}{l}\leftarrow+\text { Agro-pasture } \\
\quad \text { expansion } \\
\leftarrow-\text { Forest reserves } \\
\leftarrow+\text { Dry season severity }\end{array}$ & $\begin{array}{l}\text { Nepstad et al. }(2001,2006) \text {, Aragão et al. } \\
\quad(2007,2008)\end{array}$ \\
\hline Cattle herd & $\begin{array}{l}\leftarrow+\text { High fertility } \\
\leftarrow+\text { Subsidized credits } \\
\leftarrow+\text { Age of householders } \\
\leftarrow+\text { Number of } \\
\quad \text { inhabitants }\end{array}$ & $\begin{array}{l}\text { Andersen and Reis (1997), Faminow } \\
\text { (1997), Perz (2001), Arima et al. } \\
\text { (2005), Brondizio and Moran (2008), } \\
\text { Browder et al. (2008) }\end{array}$ \\
\hline
\end{tabular}

\begin{tabular}{|c|c|c|}
\hline Per capita income & $\begin{array}{c}\leftarrow+\text { Agro-pasture } \\
\text { expansion }\end{array}$ & Browder et al. (2008), Soler et al. (2009) \\
\hline Age of householders & $\leftarrow \underset{\text { inhabitants }}{- \text { Number of }}$ & $\begin{array}{l}\text { Perz (2001), Moran, Siqueira, and } \\
\text { Brondizio (2003), Brondizio and } \\
\text { Moran (2008) }\end{array}$ \\
\hline
\end{tabular}

Notes: The positive or negative arrows indicate whether the relationship increases or decreases the corresponding concept in the first column. Relationships in italics were not significant in the correlation matrix, but mentioned by the experts. 
Table 4. Ranking of correlation intervals adopted in the data-FCM and associated weights resulting from the expert consensus.

\begin{tabular}{lccc}
\hline $\begin{array}{l}\text { Pearson correlation } \\
\text { value }\end{array}$ & $\begin{array}{c}\text { Correlation values } \\
\text { ranked into } \\
\text { weights }\end{array}$ & $\begin{array}{c}\text { Expert consensus } \\
\text { on relationship's } \\
\text { importance }\end{array}$ & $\begin{array}{c}\text { Associated weight } \\
\text { to expert } \\
\text { consensus }\end{array}$ \\
\hline$>0.450$ & 0.9 & Strong & 0.8 \\
$0.400-0.450$ & 0.8 & Medium & \\
$0.350-0.400$ & 0.7 & & 0.5 \\
$0.300-0.350$ & 0.6 & Weak & \\
$0.250-0.300$ & 0.5 & Not significant & 0.25 \\
$0.200-0.250$ & 0.4 & & 0.1 \\
$0.150-0.200$ & 0.3 & & \\
$0.100-0.150$ & 0.2 & &
\end{tabular}

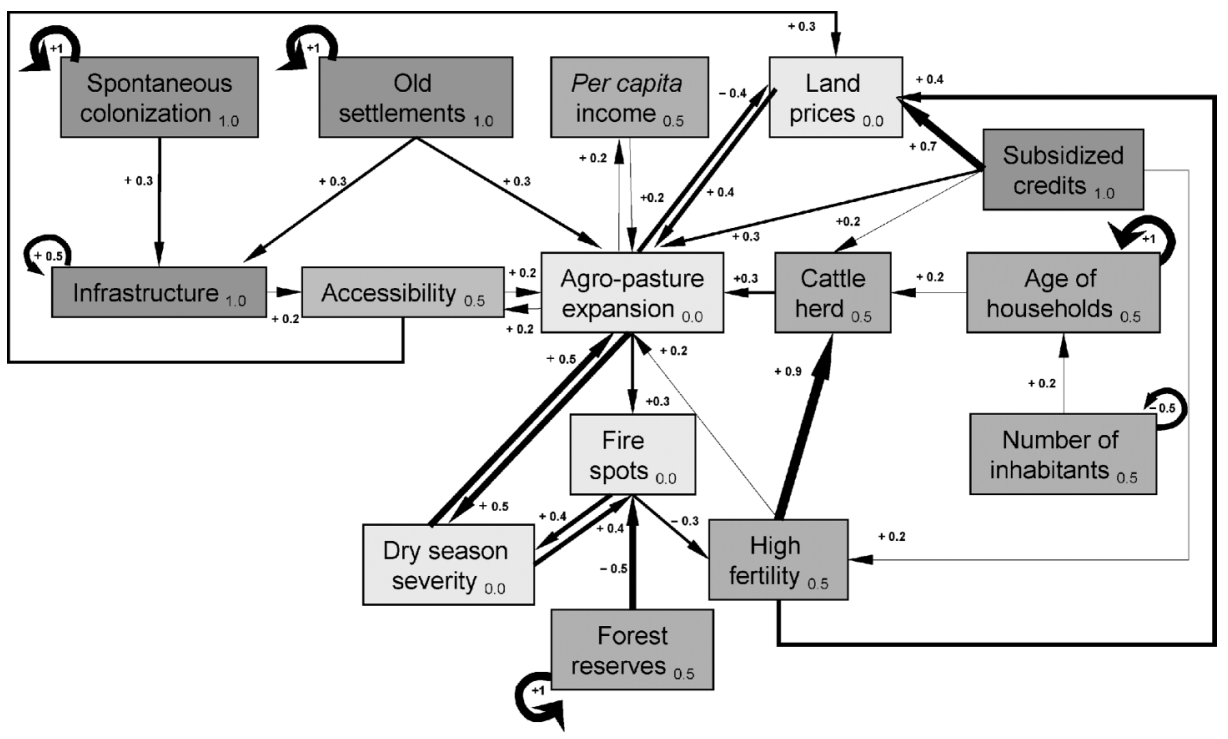

Figure 5. Graphical form of the fuzzy cognitive map (data-FCM) resulted from combining correlation matrix and literature review of expert knowledge. The weights of each relationship are indicated next to their corresponding arrows and initial state values of concepts are given inside their boxes.

relationships $\left(C_{i} \rightarrow C_{i}\right)$. In general, concepts with no input from other concepts need a selfreinforcing relationship to sustain their influence in the FCM. The resulting FCM (dataFCM) can also be represented in a graphic form, as illustrated in Figure 5.

\section{Interpreting FCM outputs}

The interpretation of a FCM is made, keeping in mind the semi-quantitative nature of numbers representing the concepts and weights. The interpretation of FCM outputs is done by comparing the final state values of concepts after the system stabilization.

The data-FCM stabilized after 10 iterations (Figure 6) and reflects the current system dynamics in Rondônia State, that is, with high final state values for agro-pasture expansion (1.42) driven by dry season severity $(0.93)$ and a relative high value of fire spots $(0.55)$ and accessibility (0.52). The final state values of subsidized credits (1.00), infrastructure (1.20), 


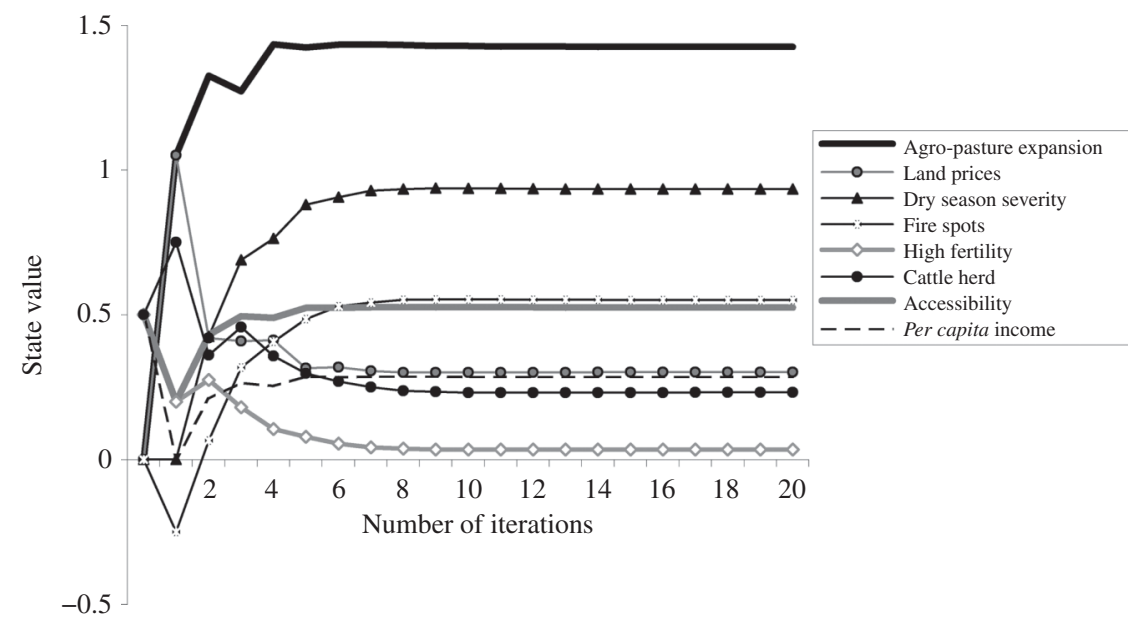

Figure 6. Graphical outputs of 20 step iterations using the fuzzy cognitive map resulted from the method proposed (data-FCM). The system stabilization is reached after 10 iterations.

old settlements (1.00), spontaneous colonization (1.00) and conservation units (0.50) were also indicated in the resulting FCM as important determinants of the system. However, their dynamic outputs, that is, the new state values of these concepts, resultant from all iterations were constant and therefore not included in the graphical FCM. The final state values of land prices $(0.30)$, per capita income $(0.28)$ and cattle herd $(0.23)$ indicated that they play a less important role in the regional agro-pasture expansion. The low state value of high fertility (0.03) indicates that this determinant plays a less important role in the land systems in Rondônia when compared with the other determinants. This can be due to the low frequency of high fertile soils in the region (Fearnside 1986; Cochrane, T.T. and Cochrane, T.A. 2006).

\subsection{Analysis of interactions and feedback mechanisms}

The analysis of the initial iterations shows that agro-pasture stabilization occurs due to the combined effect of a number of concepts, particularly land prices, subsidized credits, dry season severity and old settlements. Land prices are weakly influenced by the negative feedback mechanism with agro-pasture expansion, but stabilize due to the interaction with subsidized credits. Accessibility contributed significantly towards stabilizing land prices, which indicates the gradual stabilization of land markets in old frontiers that are more accessible to local markets. Infrastructure contributed towards stabilizing accessibility similarly to its feedback with agro-pasture expansion, which indicates that deforestation can occur before infrastructure expansion as, for example, in logging activities in the region (Matricardi, Skole, Cochrane, Pedlowski, and Chomentowski 2007). Fire spots stabilized in a positive trend due to the contribution of agro-pasture expansion and dry season severity, even though the latter is less important.

Agro-pasture expansion determined the increase in fire spots rather than the feedback mechanism with dry season severity. However, by removing this feedback dry season severity is decreased by $26 \%$ and fire spots by $70 \%$. Agro-pasture expansion also determined dry season severity and per capita income. By removing the contribution of agro-pasture in such feedbacks, dry season severity and per capita income decreased by $96 \%$, whereas agro-pasture expansion decreased by $26 \%$. The data-FCM indicates that the feedbacks among agro-pasture expansion, land prices and dry season severity drive the system in 
a more significant way than the feedbacks between agro-pasture and accessibility or per capita income.

The proposed method has indicated coherent outputs regarding the relative differences of importance of determinants of deforestation and their interactions in the case study adopted. However, a sensitivity analysis of the main outputs of the data-FCM is done in the next section to identify potential limitations of the method. Also, in the subsequent sections we develop a scenario analysis based on the data-FCM and compare the reliability of the outputs to published results using spatially explicit models of land use/land cover change. Only then is it possible to address the conclusions about the advantage of building FCM based on spatial data rather than on participatory approaches and endorse the consistency between demand and allocation in scenario analysis.

\section{Incorporating expert knowledge}

Although the direct link between weights and Pearson correlations is an objective procedure, an inherent uncertainty is present. Scale issues and inaccuracy of spatial data, as well as spatial autocorrelation among variables, can affect correlation values (Veldkamp et al. 2001, 2004; Overmars, De Koning, and Veldkamp 2003). To evaluate such uncertainties, we performed semi-structured interviews with experts to capture their interpretation of significant concepts and relationships. In total 10 experts were interviewed including land use modellers, ecologists, agronomists, biologists and social scientists from INPE (National Institute for Space Research), MPEG (Museu Paraense Emílio Goeldi) and UFRJ (Federal University of Rio de Janeiro). They were selected by their relevant scientific background in Amazonian deforestation studies and their influence on the policy decisions.

Using the concepts and the causal relationships adopted in the data-FCM, the interviewed experts were asked to rank the relative importance of each relationship (strong, medium and weak). The outcome of each interview was depicted as a FCM. Consequently, a consensual opinion from experts was obtained for each relationship and ranked into numerical weights according to Table 4 . The experts mentioned three relationships not significant in the correlation matrix and one relationship with supporting literature. These relationships were not included in the data-FCM and only considered in the sensitivity analysis. Using the weights from expert consensus and the data-FCM structure, we obtained a new adapted FCM, called expert-FCM illustrated by Figure 7.

The expert-FCM stabilized after 20 iterations and the final state values of dry season severity (4.65) and fire spots (4.46) indicate that these concepts are strong determinants of agro-pasture expansion. Per capita income (2.32) and accessibility (1.81) are also important drivers of agro-pasture expansion. However, cattle herd (0.13) and land prices (-1.28) have little influence on the system, which diverges from the literature (Andersen and Reis 1997; Margulis 2004; Sills and Caviglia-Harris 2008). Similar to the data-FCM, high fertility (-1.34) had little influence on agro-pasture expansion, even though this relationship had only been observed at the household level (Witcover, Vosti, Carpentier, and Gomes 2006; Soler and Verburg 2010).

\subsection{Spatial data versus expert knowledge}

The semi-quantification of weights of relationships can be taken as the main weakness when comparing two FCMs built with the same relationships, but with distinct weights as the expert-FCM and the data-FCM. Despite that, the normalization of concepts and the final state values can provide a partial link to qualitative outputs and facilitate the comparison between these two FCMs. However, the concepts representing variables acting at distinct temporal scales cannot be well represented as the number of iterations in an 


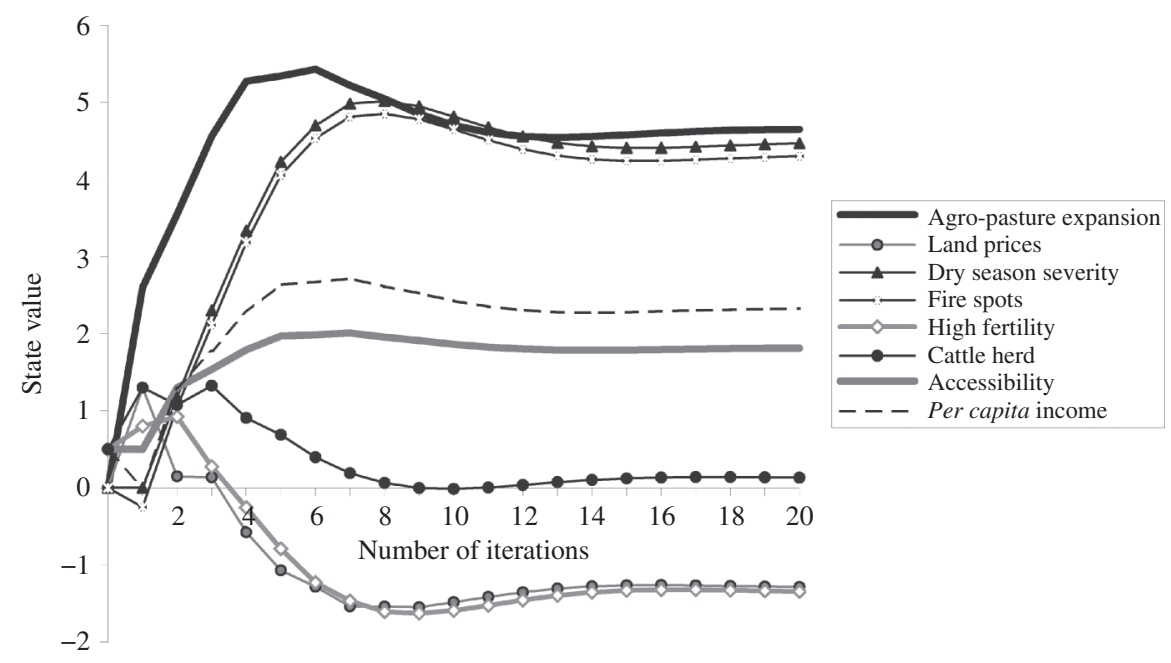

Figure 7. Graphical outputs of 20 step iterations using the fuzzy cognitive map (expert-FCM) resulted from the combination of 1) the data-FCM structure, given by the correlation matrix; and 2 ) the strengths among relationships given by expert consensus. The system stabilization is reached after 20 iterations.

FCM cannot be directly translated into temporal units. Spatial and temporal issues have no simple solution especially in a FCM representation, and they must be taken into account when interpreting and comparing two FCMs.

The comparison between normalized state values of the data-FCM and the expertFCM indicated that agro-pasture expansion, high fertility, cattle herd and forest reserves were quite similar in both FCMs. The higher outcomes in the expert-FCM were striking when compared to the data-FCM for the final state values of fire spots (166\%), per capita income $(120 \%)$ and dry season severity (92\%). In contrast, significant higher state values were observed in the data-FCM compared to the expert-FCM for infrastructure (131\%), subsidized credits $(103 \%)$, land prices $(72 \%)$, spontaneous colonization $(103 \%)$ and old settlements $(103 \%)$. Such differences are mostly due to the concepts acting at longer time scales (e.g. fire spots and dry season severity) in the expert-FCM, whereas in the data-FCM concepts acting at similar spatial scales showed higher state values.

These results indicate the inherent limitations of the method, that is, the expert opinion gives higher importance to long-term variables that have a high impact on deforestation (Nepstad et al. 1999; Aragão et al. 2008) but cannot be appropriately represented in a FCM specially when built from correlation values of one single year. On the contrary, the data-FCM seems to show higher importance for concepts acting at similar temporal and spatial scales. Although the importance of most feedback mechanisms was similar to the stabilization of both FCMs, the more evident hectic behaviour of concepts during the initial iterations in the data-FCM indicates a higher influence of feedback mechanisms than in the expert-FCM.

\subsection{Sensitivity analysis of relationships}

The divergence of strengths of causal relationships between the data-FCM and the expertFCM was evaluated. Two levels of disagreement between the two FCMs were considered: a disagreement (a mismatch within 0.2-0.4) and a strong disagreement (a mismatch $\geq 0.5$ ), 
as illustrated in Table 5. By adding an external concept, representing land demand or public policies and by exploring the weights between this concept and the existing ones, it is possible to draw conclusions about the sensitivity of the relationships. Sensitive relationships are assumed to cause a change of $\geq 0.5$ in the state value of agro-pasture expansion in the data-FCM and are indicated in the last column of Table 5.

Taking into account the 24 relationships included in the data-FCM, a total of 12 were identified as sensitive. Additionally, two relationships not included in the data-FCM but mentioned by the experts were also identified as sensitive. Out of 12 sensitive relationships in the data-FCM, 4 presented a disagreement and 5 presented a strong disagreement.

Only $20 \%$ of the relationships in the data-FCM presented a strong disagreement to the expert-FCM, which indicates a reasonable coherence of the proposed method. All the relationships with a strong disagreement were sensitive, and they indicated that the weights were underestimated in the data-FCM because of data limitations concerning scale issues. Although deforested cells are given in a detailed resolution of $30 \mathrm{~m}$, subsidized credits and cattle herd are aggregated at the municipality level and high fertility is given at a much coarser scale $(1: 1,000,000)$.

The sensitive relationships with a disagreement were affected by poor data quality and spatial autocorrelation. The relationship between fire spots and high fertility was undervalued, whereas the relationship between cattle herd and high fertility was overvalued when using the correlation matrix. Spatial autocorrelation between accessibility and land prices or accessibility and forest reserves resulted in undervalued weights in the data-FCM. This occurs mainly in old settlements where highly deforested areas mask the influence of main roads.

\section{Land cover change scenarios}

In this section, the sensitive relationships are explored in a scenario analysis, as an example of application of the data-FCM. Two external concepts were added representing demand and public policies and received the initial state values of 1.0 and 0.5 , respectively. The scenarios were based on two main issues tackled with new policies by the Brazilian government in the Amazon: land reform in confrontation to forest conservation and climate change mitigation (Brazilian Goverment 2008, 2009).

(1) Land reform and conservation: The increase of both official settlements and spontaneous colonization is considered to- be a cause of significant deforestation (Fearnside 1993; Alves et al. 2003; Brandão and Souza 2006; Ludewigs, D'antona, Brondizio, and Hetrick 2009). However, deforestation is controlled by law enforcement over forest reserves and indigenous lands (Nepstad et al. 2006; Soares-Filho et al. 2006). In this scenario, the influence of demand on spontaneous colonization received a weight of 1.0, whereas the influence of public policies on old settlements and on conservation reserves received 1.0 and 0.5 , respectively.

(2) Climate change mitigation: We consider public policies that cut subsidies and stimulate forest conservation through environmental services rewards (Borner and Wunder 2008; Fearnside 2008a). However, we depict a scenario with intensification of dry season severity as a response to climate change (Malhi et al. 2009). In this scenario, the influence of demand on dry season severity receives a weight of 1.0, whereas the influence of public policies on subsidized credits and conservation reserves receives -0.5 and 1.0 , respectively. 
L.S. Soler et al.

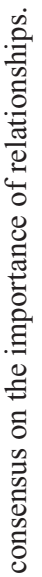

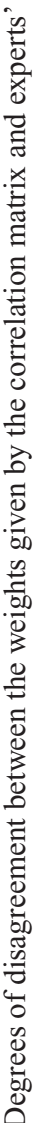

in

$\frac{0}{\frac{0}{0}}$

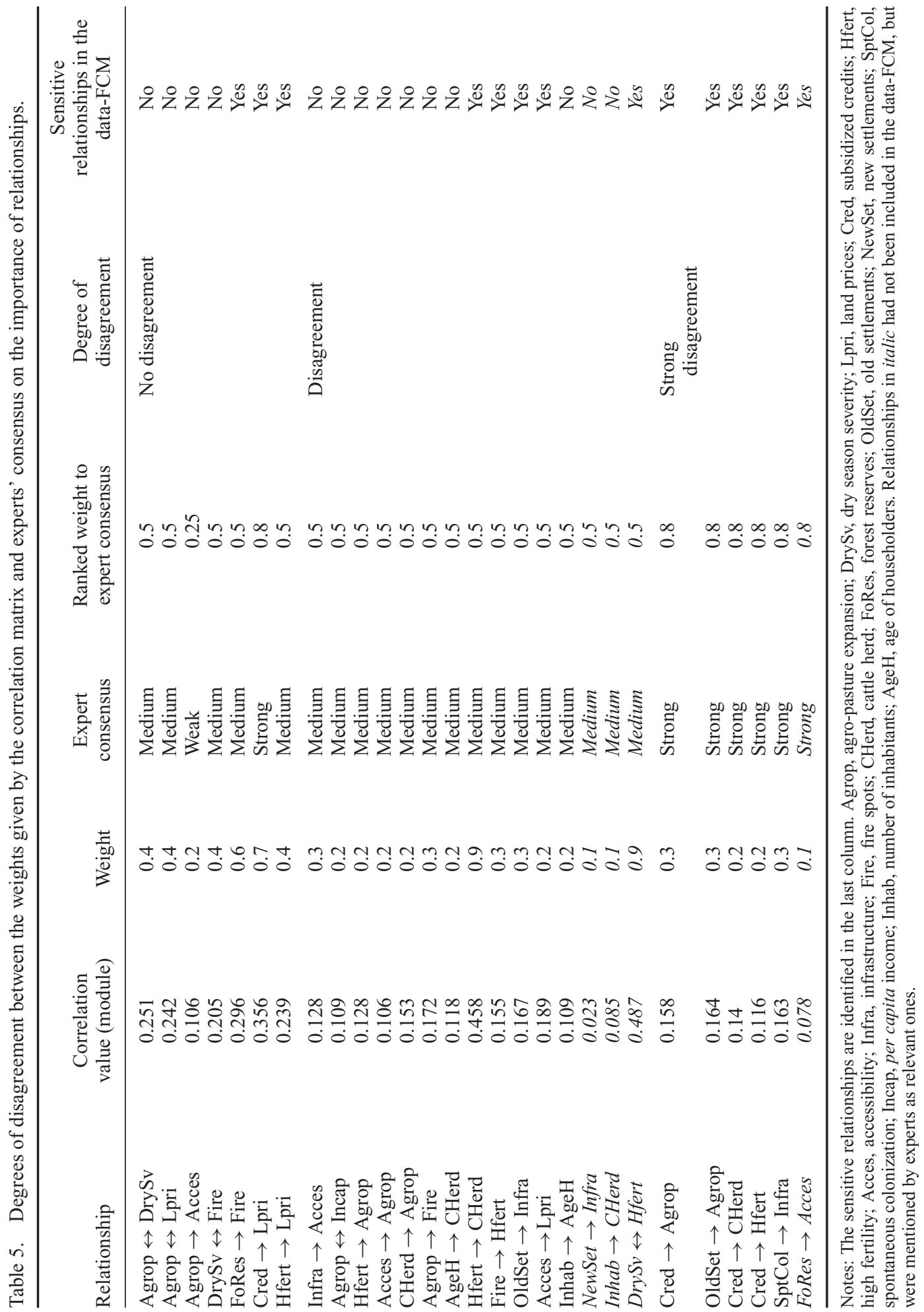


Land reform and conservation
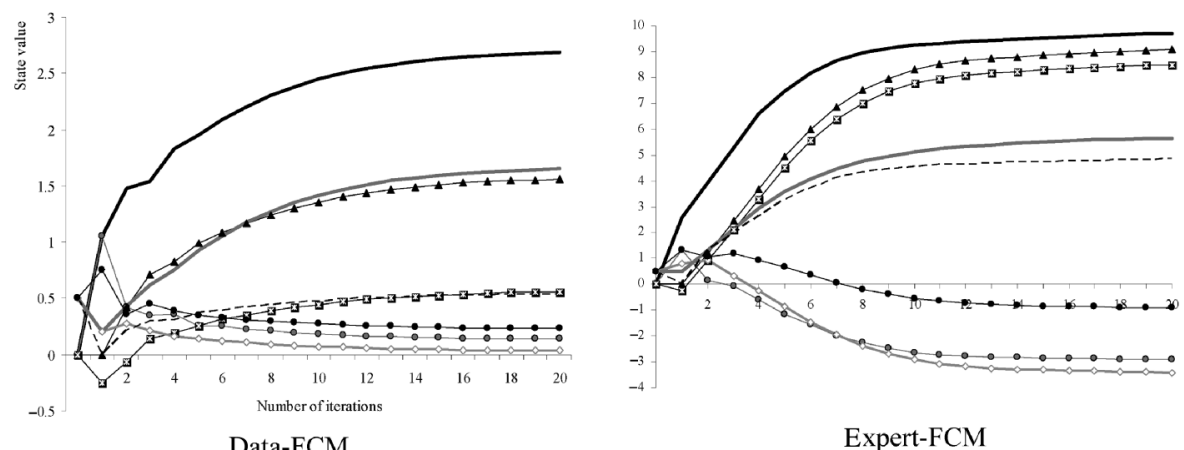

Expert-FCM

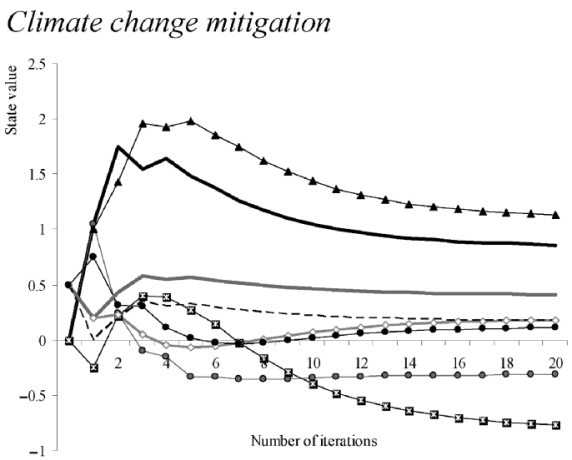

Data-FCM

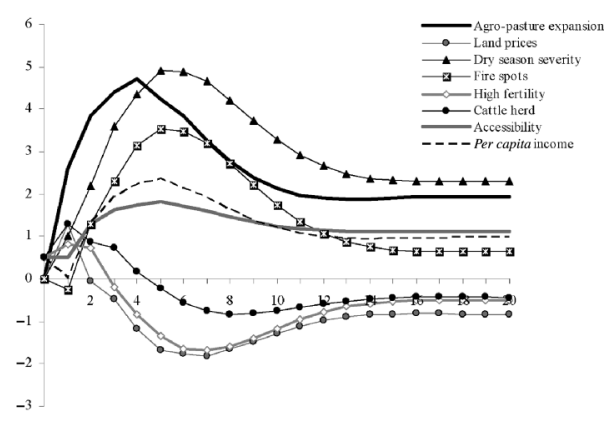

Expert-FCM

Figure 8. Graphical outputs of data-FCM and expert-FCM under the two different scenarios proposed. Final state values of concepts are not normalized in the graphics.

The scenarios evaluation was made, comparing the variation of the final state values within the same system (data-FCM or expert-FCM) to their respective scenarios illustrated in Figure 8. Normalized state values were assessed as an attempt to compare the data-FCM and the expert-FCM.

Similar to the current situation, the expert-FCM presented higher amplitude of the final state values than the data-FCM for both scenarios. The land reform and conservation policies scenario indicated a relevant increase on deforestation (i.e. agro-pasture expansion) for both the expert-FCM (9.70) and the data-FCM (2.68), although the latter to a smaller extent. This difference is due to a higher (indirect) contribution of spontaneous colonization to the final state value of accessibility (5.65) in the expert-FCM, in comparison to the data-FCM (1.65). Note that neither FCM indicated a decrease on deforestation rates with law enforcement over forest reserves, but in the data-FCM forest reserves equalized fire spots $(0.55)$, soil fertility $(0.03)$ and cattle herd $(0.23)$ to the current situation. This indicates a more optimistic trend of land impoverishment.

In the climate change mitigation scenario, both FCMs showed a decrease in deforestation particularly because of reduced subsidies. Agro-pasture expansion in the data-FCM and in the expert-FCM was 0.86 and 1.93 , respectively. Thus, the stabilization of a concept in a FCM does not mean its stagnation. In both systems dry season severity and fire spots decreased significantly under the influence of public policies over forest reserves, 
which reflects the role of protected areas in regulating rainfall patterns (Walker et al. 2009). In addition, the data-FCM indicated a more positive scenario of high soil fertility (0.18) and cattle herd (0.11), with decreased fire spots $(-0.77)$. This scenario suggests that agropasture expansion might not be directly stopped by intensified dry seasons, but they can disturb the resilience of land system and notably affect agro-pasture activities (Laurance and Williamson 2001; Aragão et al. 2007; Malhi et al. 2009). A return to current degree of resilience is suggested by both systems with high subsidies.

\subsection{Qualitative outputs of scenario analysis}

To evaluate the applicability of scenario analysis using FCMs, the normalized scenario outputs are compared to the output of similar scenarios assessed by spatial models of deforestation in the Brazilian Amazon (see Table 6). The different outputs were normalized based on the data-FCM in the current situation.

Aguiar (2006) presented projection of deforestation over 23 years using spatial data at macro- and mesoscale. The results are presented for some hot spots of deforestation from which we took the Transamazon highway case that was to be compared with the FCMs outputs. Soares-Filho et al. (2004) simulated two scenarios of deforestation at local scale over 30 years, with detailed spatial data for the Transamazon highway among other three areas. Dale, Oneill, Southworth, and Pedlowski (1994) simulated deforestation models at the property scale in Rondônia State using spatial data at fine scale. The authors simulated a best-case scenario with innovative land practices and a typical case scenario where the whole property, including its legal reserve, is deforested after 20 years.

Deforestation rates obtained in the scenarios of spatial models are reasonably comparable to the rates obtained in the FCMs. Similar deforestation rates between the FCMs outputs under the current situation and the accessibility scenario presented by Aguiar (2006) can be

Table 6. Comparison among relative deforestation rates simulated by spatial models and outputs of fuzzy cognitive maps based on spatial data and expert consensus.

\begin{tabular}{|c|c|c|c|c|c|}
\hline \multicolumn{3}{|c|}{$\begin{array}{l}\text { Normalized deforestation rates obtained from } \\
\text { spatial models }\end{array}$} & \multicolumn{3}{|c|}{ Fuzzy cognitive maps normalized outputs } \\
\hline Case study & Scenarios & & Scenarios FCM & Data-FCM & expert-FCM \\
\hline \multicolumn{6}{|l|}{$\begin{array}{l}\text { Aguiar (2006) } \\
\text { mesoscale: }\end{array}$} \\
\hline Transamazon highway & Accessibility & 1.86 & Current situation & 1.77 & 1.75 \\
\hline (Rurópolis/Trairão) & $\begin{array}{l}\text { Control of } \\
\text { deforestation }\end{array}$ & 1.92 & $\begin{array}{l}\text { Climate change } \\
\text { mitigation }\end{array}$ & 0.40 & 1.16 \\
\hline \multicolumn{6}{|l|}{$\begin{array}{l}\text { Soares-Filho et al. } \\
(2004)\end{array}$} \\
\hline local scale: & $\begin{array}{l}\text { Business as } \\
\text { usual }\end{array}$ & 0.76 & Current situation & 1.77 & 1.75 \\
\hline Transamazon highway & Governance & 0.31 & $\begin{array}{l}\text { Land reform and } \\
\text { conservation }\end{array}$ & 0.63 & 1.64 \\
\hline $\begin{array}{l}\text { Dale et al. (1994) } \\
\text { property level: }\end{array}$ & Typical case & 2.95 & Current situation & 1.77 & 1.75 \\
\hline Ouro Preto d'Oeste & Best case & 1.24 & $\begin{array}{l}\text { Land reform and } \\
\text { conservation }\end{array}$ & 0.63 & 1.64 \\
\hline
\end{tabular}


due to a higher similarity in the scenarios assumptions. Moreover, this case study adopted spatial data and scale of analysis comparable to our case study in Rondônia State.

In the scenarios presented by Soares-Filho et al. (2004), lower deforestation rates were obtained in comparison with both FCMs outputs, although in the data-FCM under the land reform and conservation scenario the difference was smaller. Plausible reasons are the use of detailed fieldwork information and different assumptions in conservation policies between the land reform and conservation and the governance scenario. At the property level, the simulated changes by Dale et al. (1994) under the typical case scenario were almost twofold higher than both FCMs under the current situation. Differences between the best case and the land reform and conservation scenarios were relevant in the dataFCM. This incongruence at the fine spatial scale is likely due to drivers and processes acting at smaller scales than our regional case study accounts for, which might limit the exemplified application.

\section{Strong and weak points of the proposed method}

Reproducibility and robustness can be considered the strongest points of the proposed method, in comparison with participatory methods of building FCMs. The main similarities between the data-FCM and the expert-FCM were the equalized final state values of agro-pasture expansion and the importance of most feedback mechanisms. Furthermore, feedback mechanisms between agro-pasture expansion and land prices and between agropasture expansion and dry season severity have shown coherent responses to the literature (Nepstad et al. 2001; Aragão et al. 2007; Sills and Caviglia-Harris 2008), which reinforces the structure based on the correlation matrix.

The weakest points of the method are arguably data and literature availability limiting the identification of causal relationships. The semi-quantification of relationships was most limited by pitfalls intrinsic to empirical and multi-level data analysis such as scale issues, poor data quality and spatial autocorrelation. Processes occurring at different time scales were poorly captured in the correlation matrix (as the increase of fire spots with drier periods). Feedbacks between fire spots and high fertility and between accessibility and land prices were undervalued in the data-FCM, as a result of poor data quality and spatial autocorrelation. Different data aggregation of subsidized credits and per capita income as well as incomplete land tenure data resulted in undervalued relationships in the data-FCM.

In the scenario analysis, regional processes are better simulated in the data-FCM (e.g. soil impoverishment due to the increase on fire spots). On the contrary, the expert-FCM translated better processes occurring at broader scales, for instance, the role of forest reserves in rainfall patterns. Despite this, both systems indicated the high sensitivity of conservation policies being negatively affected by the current paradigm of agrarian settlements and existing subsidized credits (Pedlowski et al. 2005; Pacheco 2009) and positively affected when subsidies are removed. The qualitative comparison of scenarios outputs between spatial models and FCMs indicated that the latter provide coherent demands of change. Limitations lie on data availability and scale dependence of processes within the case study adopted.

\section{Conclusions}

By using the data-FCM in scenario analysis, it is possible to evaluate the sensitivity of governance and to assess rates of land cover change comparable to spatially explicit model outputs. Thus, the data-FCM can be used as a new method of scenario analysis. We argue 
that by incorporating the proposed method to spatially explicit models we endorse the consistency between demand and allocation. In addition, we prevent the potential incongruence of considering divergent realities from stakeholders or too different backgrounds given by experts' consensus.

The resulting FCM based on spatially explicit data has proved to be a coherent tool to assess land cover change scenarios. Even though there are no strong arguments to claim that the data-FCM is more suitable than the expert-FCM for scenario analysis, the data-FCM represents a more robust and reproducible method. The main limitations of the method lie in on data and literature availability as well as spatial and temporal scaling issues when dealing with multi-level data.

Because of data-FCM limitations, expert-FCM can be claimed to be more suitable to assess more realistic scenario analyses. However, the robustness and reproducibility of this method are compromised as the same group of experts could suggest different strengths and relationships according to current land system dynamics and environmental policies agenda. Even though the expert-FCM was useful as a means to reveal spatial data limitations as autocorrelation, its structure mirrored the data-FCM structure and is under the influence of similar limitations as data availability, scaling issues and literature availability. Therefore, expert-FCM could be used as a complementary step to the proposed data-FCM to diminish data limitation issues.

\section{Acknowledgements}

This research was funded by the Dutch National Science Foundation (NWO-WOTRO) project "Vulnerability and resilience of the Brazilian Amazon forests and human environment to changes in land use and climate". The authors would like to thanks Dalton Valeriano, Diógenes Alves, Ana Paula Aguiar, Roberto Araújo, João Roberto dos Santos, Cláudio Almeida and Cláudio Linhares for sharing their knowledge during the interviews performed.

\section{References}

Aguiar, A.P.D. (2006), "Modeling Land Use Change in the Brazilian Amazon: Exploring Intraregional Heterogeneity," Ph.D dissertation, National Institute for Space Research (INPE), São José dos Campos SP, Brazil.

Aguiar, A.P.D., Câmara, G., and Escada, M.I.S. (2007), "Spatial Statistical Analysis of Land-Use Determinants in the Brazilian Amazonia: Exploring Intra-regional Heterogeneity," Ecological Modelling, 209(2-4), 169-188.

Alves, D.S. (2002), "Space-Time Dynamics of Deforestation in Brazilian Amazonia," International Journal of Remote Sensing, 23(14), 2903-2908.

Alves, D.S. (2008), "Taking Things Public: A Contribution to Address Human Dimensions of Environmental Change," Philosophical Transactions of the Royal Society B-Biological Sciences, 363(1498), 1903-1909.

Alves, D.S., Escada, M.I.S., Pereira, J.L.G., and Linhares, C.D. (2003), "Land Use Intensification and Abandonment in Rondonia, Brazilian Amazonia," International Journal of Remote Sensing, 24(4), 899-903.

Alves, D.S., Pereira, J.L.G., Sousa, C.L.D., Soares, J.V., and Yamaguchi, F. (1999), "Characterizing Landscape Changes in Central Rondonia Using Landsat TM Imagery," International Journal of Remote Sensing, 20(14), 2877-2882.

Andersen, L.E., and Reis, E.J. (1997), "Deforestation, Development and Government Policy in the Brazilian Amazon: An Econometric Analysis," Instituto de Pesquisa Econômica Aplicada (IPEA), 27.

Aragão, L.E.O.C., Malhi, Y., Barbier, N., Lima, A., Shimabukuro, Y., Anderson, L., and Saatchi, S. (2008), "Interactions Between Rainfall, Deforestation and Fires During Recent Years in the Brazilian Amazonia," Philosophical Transactions of the Royal Society B-Biological Sciences, 363(1498), 1779-1785. 
Aragão, L.E.O.C., Malhi, Y., Roman-Cuesta, R.M., Saatchi, S., Anderson, L.O., and Shimabukuro, Y.E. (2007), "Spatial Patterns and Fire Response of Recent Amazonian Droughts," Geophysical Research Letters, 34(7).

Arima, E.Y., Barreto, P., and Brito, M. (2005), "Cattle Ranching in the Amazon: Trends and Implications for Environmental Conservation, Belém: IMAZON.

Arima, E.Y., Walker, R.T., Sales, M., Souza, C., and Perz, S.G. (2008), "The Fragmentation of Space in the Amazon Basin: Emergent Road Networks," Photogrammetric Engineering and Remote Sensing, 74(6), 699-709.

Axelrod, R. (1976), Structure of Decision: The Cognitive Maps of Political Elites, Princeton: Princeton University Press.

Becker, B. (2004), Amazônia: Geopolítica na virada do III milênio, Rio de Janeiro: Garamond.

Borner, J., and Wunder, S. (2008), "Paying for Avoided Deforestation in the Brazilian Amazon: From Cost Assessment to Scheme Design," International Forestry Review, 10(3), 496-511.

Brandão, A.O., and Souza, C. (2006), Deforestation in Land Reform Settlements in the Amazon. Belém: IMAZON.

Brandão, A.O., Souza, C.M., Ribeiro, J.G.F., and Sales, M.H.R. (2007), "Deforestation and unofficial roads in the Amazon," in XIII Brazilian Symposium of Remote Sensing, Florianópolis, Brazil, pp. $2357-2364$.

Brasil, (2007), Anuário estatístico do crédito rural 2000-2007. Banco Central do Brasil.

Brazilian Government (2008), "Brazilian National Plan on Climate Change" Decree $n^{\circ} 6.263,21^{s t}$ November 2007, 154. Available from: http://www.brasil.gov.br/pac.

Brazilian Government (2009), Provisional Measure (MP) number 458/09, implemented on $10^{\text {th }}$ February 2009. Available from: http://www.brasil.gov.br.

Brondizio, E.S., and Moran, E.F. (2008), "Human Dimensions of Climate Change: The Vulnerability of Small Farmers in the Amazon," Philosophical Transactions of the Royal Society B-Biological Sciences, 363(1498), 1803-1809.

Browder, J.O. (1988), "Public Policy and Deforestation in the Brazilian Amazon," In Public Policies and the Misuse of Forest Resources, eds. R. Repetto and M. Gillis, Cambridge: Cambridge University Press, pp. 247-283.

Browder, J.O. (1994), "Surviving in Rondonia - The Dynamics of Colonist Farming Strategies in Brazil Northwest Frontier," Studies In Comparative International Development, 29(3), 45-69.

Browder, J.O., Pedlowski, M.A., Walker, R., Wynne, R.H., Summers, P.M., Abad, A., BecerraCordoba, N., and Mil-Homens, J. (2008), "Revisiting Theories of Frontier Expansion in the Brazilian Amazon: A Survey of the Colonist Farming Population in Rondonia's Post-Frontier, 1992-2002," World Development, 36(8), 1469-1492.

Câmara, G., Paula, A., Aguiar, D., Escada, M.I., Amaral, S., Carneiro, T., Monteiro, A.M.V., Araujo, R., Vieira, I., and Becker, B. (2005), "Amazonian Deforestation Models," Science, 307(5712), $1043-1044$.

Carley, K., and Palmquist, M. (1992), "Extracting, Representing, and Analyzing Mental Models," Social Forces, 70(3), 601-636.

Chomitz, K.M., and Thomas, T.S. (2003), "Determinants of Land Use in Amazonia: A Fine-Scale Spatial Analysis," American Journal of Agricultural Economics, 85, 1016-1028.

Claessens, L., Schoorl, J.M., Verburg, P.H., Geraedts, L., and Veldkamp, A. (2009), "Modelling Interactions and Feedback Mechanisms Between Land Use Change and Landscape Processes," Agriculture Ecosystems \& Environment, 129(1-3), 157-170.

Cochrane, T.T., and Cochrane, T.A. (2006), "Diversity of the Land Resources in the Amazonian State of Rondônia, Brazil," Acta Amazonica, 36(1), 91-102.

Cossette, P., and Audet, M. (1992), "Mapping of an Idiosyncratic Schema," Journal of Management Studies, 29(3), 325-347.

Coy, M. (1987), "Rondônia: frente pioneira e o programa polonoroeste. O processo de diferenciação sócioeconômica na periferia e os limites do planejamento público," Tubinguen Geographische Studien, 95, 253-270.

CPRM (2004), Carta Geológica do Brasil ao Milionésimo, folha SC-20, 1:1.000.000, Rio de Janeiro: CPRM.

Dale, V.H., Oneill, R.V., Southworth, F., and Pedlowski, M. (1994), "Modeling Effects of Land Management in the Brazilian Settlement of Rondonia," Conservation Biology, 8(1), 196-206.

Escada M.I.S. (2003), 'Evolução de padrões da terra na região Centro-Norte de Rondônia' Ph. D dissertation, National Institute for Space Research (INPE), São José dos Campos, SP, Brazil. 
Faminow, M.D. (1997), "Spatial Economics of Local Demand for Cattle Products in Amazon Development," Agriculture Ecosystems \& Environment, 62(1), 1-11.

Fearnside, P.M. (1980), "The Effect of Cattle Pasture on Soil Fertility in the Brazilian Amazon: Consequences for Beef Production Sustainatility," Tropical Ecology, 21(1), pp. 125-137.

Fearnside, P.M. (1986), "Settlement in Rondonia and the Token Role of Science and Technology in Brazil Amazonian Development-Planning," Interciencia, 11(5), 229-236.

Fearnside, P.M. (1993), "Deforestation in Brazilian Amazonia: The Effect of Population and Land Tenure," Ambio, 22(8), 537-545.

Fearnside, P.M. (2003), "Conservation Policy in Brazilian Amazonia: Understanding the Dilemmas," World Development, 31(5), 757-779.

Fearnside, P.M. (2005), "Deforestation in Brazilian Amazonia: History, Rates, and Consequences," Conservation Biology, 19(3), 680-688.

Fearnside, P.M. (2008a), "Amazon Forest Maintenance as a Source of Environmental Services," Anais Da Academia Brasileira De Ciencias, 80(1), 101-114.

Fearnside, P.M. (2008b), "The Roles and Movements of Actors in the Deforestation of Brazilian Amazonia," Ecology and Society, 13(1), p. 23. Available from: http://www.ecologyandsociety.org.

Fearnside, P.M., and Graca, P.M.L.D. (2006), "BR-319: Brazil's Manaus-Porto Velho Highway and the Potential Impact of Linking the Arc of Deforestation to Central Amazonia," Environmental Management, 38(5), 705-716.

Fujisaka, S., Bell, W., Thomas, N., Hurtado, L., and Crawford, E. (1996), "Slash-and-burn Agriculture, Conversion to Pasture, and Deforestation in Two Brazilian Amazon Colonies," Agriculture Ecosystems \& Environment, 59(1-2), 115-130.

Geist, H., Mcconnell, W.J., Lambin, E.F., Moran, E.F., Alves, D.S., and Rudel, T. (2006), "Causes and Trajectories of Land-Use/Cover Change," In Land-Use and Land-Cover Change: Local Processes and Global Impacts (1st ed.), eds. E.F. Lambin and H. Geist, Berlin: Springer, p. 222.

Hecht, S.B. (1985), “Environment Development and Poltics: Capital Accumulation and the Livestock in Easten Amazonia" World Development, 13(6), pp. 663-684.

Hughes, R.F., Kauffman, J.B., and Cummings, D.L. (2002), "Dynamics of Aboveground and Soil Carbon and Nitrogen Stocks and Cycling of Available Nitrogen Along a Land-Use Gradient in Rondonia, Brazil," Ecosystems, 5(3), 244-259.

IBAMA (2005), Online database [online]. MMA (Ministério do Meio Ambiente). Instituto Brasileiro do Meio Ambiente e dos Recursos Naturais Renováveis, Available from: http://www.ibama. gov.br.

IBGE (2000), Censo demográfico 2000. Rio de Janeiro: Instituto Brasileiro de Geografia e Estatística (IBGE).

IDARON, (2006), Fieldwork Reports of Vaccination Campaigns Against Aftosa Fever from 1999 to 2006, Porto Velho: Agência de Defesa Sanitária Agrosilvopastoril do Estado de Rondônia.

INCRA (2007), Statistical data per category of rural property. Brazil: National Institute of Colonization and Land Reform.

INCRA (2008), Plans of Agrarian Projects in the North of Rondonia State, Ariquemes: INCRA.

INPE (2009), PRODES - Monitoring the Brazilian Amazonian Forest by Satellite Images, São José dos Campos, São Paulo: Instituto Nacional de Pesquisas Espaciais.

INPE/CPTEC (2005), Burns monitoring. São José dos Campos, São Paulo. National Institute for Space Research (INPE).

Jenkins, C.N., and Joppa, L. (2009), "Expansion of the Global Terrestrial Protected Area System," Biological Conservation, 142(10), 2166-2174.

Kok, K. (2009), "The Potential of Fuzzy Cognitive Maps for Semi-quantitative Scenario Development, with an Example from Brazil," Global Environmental Change, 19(1), 122-133.

Kosko, B. (1986), "Fuzzy Cognitive Maps," International Journal of Man-Machine Studies, 24, $65-75$.

Lambin, E.F., and Geist, H.J. (2003), „Regional Differences in Tropical Deforestation,” Environment, 45(6), 22-36.

Lambin, E.F., Turner, B.L., Geist, H.J., Agbola, S.B., Angelsen, A., Bruce, J.W., Coomes, O.T., Dirzo, R., Fischer, G., Folke, C., George, P.S., Homewood, K., Imbernon, J., Leemans, R., Li, X.B., Moran, E.F., Mortimore, M., Ramakrishnan, P.S., Richards, J.F., Skanes, H., Steffen, W., Stone, G.D., Svedin, U., Veldkamp, T.A., Vogel, C., and Xu, J.C. (2001), "The Causes of Land-Use and Land-Cover Change: Moving Beyond the Myths," Global Environmental Change-Human and Policy Dimensions, 11(4), 261-269. 
Laurance, W.F., Albernaz, A.K.M., Fearnside, P.M., Vasconcelos, H.L., and Ferreira, L.V. (2004), "Deforestation in Amazonia," Science, 304(5674), 1109-1109.

Laurance, W.F., and Williamson, G.B. (2001), "Positive Feedbacks Among Forest Fragmentation, Drought, and Climate Change in the Amazon," Conservation Biology, 15(6), 1529-1535.

Liu, J., Dietz, T., Carpenter, S.R., Alberti, M., Folke, C., Moran, E., Pell, A.N., Deadman, P., Kratz, T., Lubchenco, J., Ostrom, E., Ouyang, Z., Provencher, W., Redman, C.L., Schneider, S.H., and Taylor, W.W. (2007), "Complexity of Coupled Human and Natural Systems,". Science, 317(5844), 1513-1516.

Ludewigs, T., D'antona, A.D., Brondizio, E.S., and Hetrick, S. (2009), “Agrarian Structure and LandCover Change Along the Lifespan of Three Colonization Areas in the Brazilian Amazon," World Development, 37(8), 1348-1359.

Machado, L. (ed.) (1998), A fronteira agrícola na Amazônia, São Paulo: Cia das Letras.

Malhi, Y., Aragão, L.E.O.C., Galbraith, D., Huntingford, C., Fisher, R., Zelazowski, P., Sitch, S., Mcsweeney, C., and Meir, P. (2009), "Exploring the Likelihood and Mechanism of a ClimateChange-Induced Dieback of the Amazon Rainforest," Proceedings of the National Academy of Sciences, 106(49) pp. 20610-20616. Available from: http://www.pnas.org/content/early/2009/ 02/12/0804619106.abstract

MAPA, (2008), List of Slaughterhouses and Diary Industries Certified by the Federal Inspection Agency, 106(49) pp. 20610-20616. Brasilia: Serviço de Inspeção Federal - Ministério da Agricultura, Pecuária e Abastecimento.

Margulis, S. (2004), Causes of Deforestation in the Brazilian Amazon. Washington, DC: World Bank, p. 22.

Matricardi, E.A.T., Skole, D.L., Cochrane, M.A., Pedlowski, M., and Chomentowski, W. (2007), "Multi-Temporal Assessment of Selective Logging in the Brazilian Amazon using Landsat Data," International Journal of Remote Sensing, 28(1-2), 63-82.

Microsoft (2003). Microsoft Office Excel. Copyright (C) 1985-2003 Microsoft Corporation.

Millikan, B.H. (1992), Tropical Deforestation, Land Degradation, and Society - Lessons from Rondonia, Brazil," Latin American Perspectives, 19(1), 45-72.

Milne, E., Aspinall, R., and Veldkamp, T. (2009), "Integrated Modelling of Natural and Social Systems in Land Change Science," Landscape Ecology, 24(9), 1145-1147.

Montazemi, A.R., and Conrath, D.W. (1986), "The Use of Cognitive Mapping for Information Requirements Analysis," MIS Quarterly, 10(1), 45-56.

Moran, E.F. (1993), "Deforestation and Land-Use in the Brazilian Amazon," Human Ecology, 21(1), $1-21$.

Moran, E.F., Siqueira, A., and Brondizio, E.S. (2003), "Household Demographic Structure and its Relationship to Deforestation in the Amazon Basin," in People and the Environment Approaches for Linking Household and Community Surveys to Remote Sensing and GIS, eds. J. Fox, R.R. Rindfuss, S.J. Walsh and V. Mishra, Dordrecht: Kluwer Academic Publishers, pp. 61-89.

Nepstad, D., Carvalho, G., Barros, A.C., Alencar, A., Capobianco, J.P., Bishop, J., Moutinho, P., Lefebvre, P., Silva, U.L., and Prins, E. (2001), "Road Paving, Fire Regime Feedbacks, and the Future of Amazon Forests," Forest Ecology and Management, 154(3), 395-407.

Nepstad, D., Schwartzman, S., Bamberger, B., Santilli, M., Ray, D., Schlesinger, P., Lefebvre, P., Alencar, A., Prinz, E., Fiske, G., and Rolla, A. (2006), "Inhibition of Amazon Deforestation and Fire by Parks and Indigenous Lands," Conservation Biology, 20(1), 65-73.

Nepstad, D.C., Verissimo, A., Alencar, A., Nobre, C., Lima, E., Lefebvre, P., Schlesinger, P., Potter, C., Moutinho, P., Mendoza, E., Cochrane, M., and Brooks, V. (1999), "LargeScale Impoverishment of Amazonian Forests by Logging and Fire," Nature, 398(6727), 505-508.

Numata, I., Soares, J.V., Roberts, D.A., Leonidas, F.C., Chadwick, O.A., and Batista, G.T. (2003), "Relationships Among Soil Fertility Dynamics and Remotely Sensed Measures Across Pasture Chronosequences in Rondonia, Brazil," Remote Sensing of Environment, 87(4), 446-455.

Overmars, K.P., De Koning, G.H.J., and Veldkamp, A. (2003)," Spatial Autocorrelation in MultiScale Land Use Models," Ecological Modelling, 164(2-3), 257-270.

Ozesmi, U., and Ozesmi, S. (2003), "A Participatory Approach to Ecosystem Conservation: Fuzzy Cognitive Maps and Stakeholder Group Analysis in Uluabat Lake, Turkey," Environmental Management, 31(4), 518-531.

Pacheco, P. (2009), "Agrarian Reform in the Brazilian Amazon: Its Implications for Land Distribution and Deforestation," World Development, 37(8), 1337-1347. 
Parker, D.C., Hessl, A., and Davis, S.C. (2008), "Complexity, Land-Use Modeling, and the Human Dimension: Fundamental Challenges for Mapping Unknown Outcome Spaces," Geoforum, 39(2), 789-804.

Parker, D.C., Manson, S.M., Janssen, M.A., Hoffmann, M.J., and Deadman, P. (2003), "Multi-Agent Systems for the Simulation of Land-Use and Land-Cover Change: A review," Annals of the Association of American Geographers, 93(2), 314-337.

Pedlowski, M.A., Dale, V.H., Matricardi, E.A.T., and Da Silva, E.P. (1997), "Patterns and Impacts of Deforestation in Rondonia, Brazil," Landscape and Urban Planning, 38(3-4), 149-157.

Pedlowski, M.A., Matricardi, E.A.T., Skole, D., Cameron, S.R., Chomentowski, W., Fernandes, C., and Lisboa, A. (2005), "Conservation Units: A New Deforestation Frontier in the Amazonian State of Rondonia, Brazil," Environmental Conservation, 32(2), 149-155.

Perz, S.G. (2001), "Household Demographic Factors as Life Cycle Determinants of Land Use in the Amazon," Population Research and Policy Review, 20(3), 159-186.

Perz, S.G., and Walker, R.T. (2002), "Household Life Cycles and Secondary Forest Cover Among Small Farm Colonists in the Amazon," World Development, 30(6), 1009-1027.

RADAMBRASIL (1978), Folha SC.20 - Porto Velho, Rio de Janeiro: IBGE.

Roberts, D.A., Numata, I., Holmes, K., Batista, G., Krug, T., Monteiro, A., Powell, B., and Chadwick, O.A. (2002), "Large Area Mapping of Land-Cover Change in Rondonia Using Multitemporal Spectral Mixture Analysis and Decision tree Classifiers," Journal of Geophysical Research-Atmospheres, 107(D20), pp. LBA 40-1-LBA 40-18.

Roberts, F.S. (1973), "Building and Analyzing an Energy Demand Signed Digraph," Environment and Planning A, 5(2), 199-221.

R-Project (2010), A Language and Environment for Statistical Computing. R Development Core Team. R Foundation for Statistical Computing. Vienna, Austria.

Schneider, R.R., Arima, E., Veríssimo, A., Barreto, P., and Souza, C.J. (2000), Sustainable Amazon: Limitations and Opportunities for Rural Development, Brasília: World Bank and IMAZON.

Scouvart, M., Adams, R.T., Caldas, M., Dale, V., Mertens, B., Nedelec, V., Pacheco, P., Rihoux, B., and Lambin, E.F. (2007), "Causes of Deforestation in the Brazilian Amazon: A Qualitative Comparative Analysis," Journal of Land Use Science, 2(4), 257-282.

Sills, E.O., and Caviglia-Harris, J.L. (2008), "Evolution of the Amazonian frontier: Land Values in Rondônia, Brazil," Land Use Policy, 26(1), 55-67.

Soares-Filho, B., Alencar, A., Nepstad, D., Cerqueira, G., Diaz, M.D.V., Rivero, S., Solorzano, L., and Voll, E. (2004), "Simulating the Response of Land-Cover Changes to Road Paving and Governance Along a Major Amazon Highway: The Santarem-Cuiaba corridor," Global Change Biology, 10(5), 745-764.

Soares-Filho, B., Nepstad, D.C., Curran, L.M., Cerqueira, G.C., Garcia, R.A., Ramos, C.A., Voll, E., Mcdonald, A., Lefebvre, P., and Schlesinger, P. (2006), "Modelling Conservation in the Amazon Basin," Nature, 440(7083), 520-523.

Soler, L.S., Escada, M.I.S., and Verburg, P.H. (2009), "Quantifying Deforestation and Secondary Forest Determinants for Different Spatial Extents in an Amazonian Colonization Frontier (Rondonia)," Applied Geography, 29(2), 182-193.

Soler, L.S., and Verburg, P.H. (2010), "Combining Remote Sensing and Household Level Data for Regional Scale Analysis of Land Cover Change in the Brazilian Amazon," Regional Environmental Change, 10(4), 371-386.

Sombroek, W. (2001), "Spatial and Temporal Patterns of Amazon Rainfall - Consequences for the Planning of Agricultural Occupation and the Protection of Primary Forests," Ambio, 30(7), 388396.

Turner II, B.L., Moran, E.F., and Rindfuss, R.R. (2004), "Integrated Land-Change Science and its Relevance to the Human Sciences," In Land Change Science: Observing, Monitoring and Understanding Trajectories of Change on the Earth's Surface, eds. G. Gutman, A.C. Janetos, C.O. Justice, E.F. Moran, and J.F. Mustard, Dordrecht/London: Kluwer Academic Publishers, pp. 431-447.

Veldkamp, A., and Fresco, L.O. (1996), "CLUE-CR: An Integrated Multi-Scale Model to Simulate Land Use Change Scenarios in Costa Rica," Ecological Modelling, 91(1-3), 231-248.

Veldkamp, A., Kok, K., De Koning, G.H.J., Schoorl, J.M., Sonnenveld, M.P.W., and Verburg, P.H. (2001), "Multi-Scale System Approaches in Agronomic Research at the Landscape Level," Soil And Tillage Research, 58, 129-140.

Veldkamp, A., and Verburg, P.H. (2004), "Modelling Land Use Change and Environmental Impact," Journal of Environmental Management, 72(1-2), 1-3. 
Verburg, P.H. (2006), "Simulating Feedbacks in Land Use and Land Cover Change Model," Landscape Ecology, 21(8), 1171-1183.

Verburg, P.H., Kok, K., Pontius Jr., R.G., and Veldkamp, A. (2006), “Modeling Land-Use and LandCover Change," In Land-Use and Land-Cover Change: Local Processes and Global Impacts (1st ed.), eds. E.F. Lambin and H. Geist, Berlin: Springer, p. 222.

Verburg, P.H., Overmars, K.P., and Witte, N. (2004), Accessibility and Land-Use Patterns at the Forest Fringe in the Northeastern Part of the Philippines," The Geographical Journal, 170(3), $238-255$.

Vliet, M., Kok, K., and Veldkamp, A. (2010), "Linking Stakeholders and Modellers in Scenario Studies; the Use of Fuzzy Cognitive Maps as a Communication and Learning Tool," Futures, $42(1), 1-14$.

Walker, R., Moore, N.J., Arima, E., Perz, S., Simmons, C., Caldas, M., Vergara, D., and Bohrer, C. (2009), "Protecting the Amazon with Protected Areas," Proceedings of the National Academy of Sciences, (106), 10582-10586.

Walker, R., Moran, E.F., and Anselin, L. (2000), "Deforestation and Cattle Ranching in the Brazilian Amazon: External Capital and Household Processes," World Development, 28(4), 683-699.

Witcover, J., Vosti, S.A., Carpentier, C.L., and Gomes, T.C.D.A. (2006), Impacts of Soil Quality Differences on Deforestation, Use of Cleared Land, and Farm Income," Environment and Development Economics, 11, 343-370. 


\section{Appendix 1}

Table A.1. Cross-analysis between correlation values (among coded variables) and literature review of expert knowledge $(N=140,000)$. Correlations are considered relevant when larger than 0.100 and significant at the 0.01 level (two-tailed).

\begin{tabular}{|c|c|c|c|}
\hline Relationship & $\begin{array}{l}\text { Significant } \\
\text { correlation }\end{array}$ & Relationship cited by relevant literature & $\begin{array}{l}\text { Data-FCM } \\
\text { and } \\
\text { expert-FCM }\end{array}$ \\
\hline Acces $\leftrightarrow$ Infra & Yes & $\begin{array}{l}\text { Alves et al. (1999), Aguiar et al. (2007), } \\
\quad \text { Arima et al. (2008), Soler et al. (2009) }\end{array}$ & $X$ \\
\hline Agrop $\leftrightarrow$ DrySv & & $\begin{array}{l}\text { Sombroek (2001), Chomitz and Thomas } \\
\text { (2003), Aragão et al. (2008) }\end{array}$ & $X$ \\
\hline Agrop $\leftrightarrow$ Lpri & & $\begin{array}{l}\text { Browder (1988), Fujisaka et al. (1996), } \\
\text { Margulis (2004), Arima et al. (2005), } \\
\text { Browder et al. (2008), Sills and } \\
\text { Caviglia-Harris (2008) }\end{array}$ & $X$ \\
\hline Agrop $\leftrightarrow$ Hfert & & $\begin{array}{l}\text { Moraes et al. (1996), Hughes et al. (2002), } \\
\quad \text { Roberts et al. (2002), Numata et al. (2003) }\end{array}$ & $X$ \\
\hline Agrop $\leftrightarrow$ Acces & & $\begin{array}{l}\text { Aguiar et al. (2007), Arima et al. (2008), Soler } \\
\text { et al. (2009) }\end{array}$ & $X$ \\
\hline Agrop $\leftrightarrow$ Fire & & $\begin{array}{l}\text { Laurance and Williamson (2001), Aragão et al. } \\
\text { (2008) }\end{array}$ & $X$ \\
\hline Agrop $\leftrightarrow$ Cred & & Andersen and Reis (1997), Arima et al. (2005) & $X$ \\
\hline Agrop $\leftrightarrow$ OldSet & & $\begin{array}{l}\text { Alves et al. (1999), Escada (2003), Brandão } \\
\text { and Souza (2006) }\end{array}$ & $X$ \\
\hline Agrop $\leftrightarrow$ CHerd & & $\begin{array}{l}\text { Fujisaka et al. (1996), Margulis (2004), Arima } \\
\text { et al. (2005) }\end{array}$ & $X$ \\
\hline Agrop $\leftrightarrow$ Incap & & $\begin{array}{l}\text { Margulis (2004), Browder et al. (2008), Soler } \\
\text { et al. (2009) }\end{array}$ & $X$ \\
\hline Cred $\leftrightarrow$ CHerd & & Faminow (1997), Arima et al. (2005) & $X$ \\
\hline $\mathrm{CHerd} \leftrightarrow \mathrm{AgeH}$ & & $\begin{array}{l}\text { Perz (2001), Moran et al. (2003), Brondizio } \\
\text { and Moran (2008) }\end{array}$ & $X$ \\
\hline DrySv $\leftrightarrow$ Fire & & $\begin{array}{l}\text { Nepstad et al. (2001), Aragão et al. (2007, } \\
\text { 2008) }\end{array}$ & $X$ \\
\hline Fire $\leftrightarrow$ FoRes & & Nepstad et al. (2006) & $X$ \\
\hline Hfert $\leftrightarrow$ Fire & & Hughes et al. (2002) & $X$ \\
\hline Hfert $\leftrightarrow$ Cred & & Fearnside (1986), Arima et al. (2008) & $X$ \\
\hline Hfert $\leftrightarrow$ CHerd & & $\begin{array}{l}\text { Fearnside (1980), Hecht (1985), Margulis } \\
\text { (2004) }\end{array}$ & $X$ \\
\hline Infra $\leftrightarrow$ OldSet & & $\begin{array}{l}\text { Alves et al. (1999), Alves (2002), Brandão and } \\
\text { Souza (2006), Brandão et al. (2007), Soler } \\
\text { et al. (2009), Soler and Verburg (accepted) }\end{array}$ & $X$ \\
\hline Infra $\leftrightarrow \mathrm{SptCol}$ & & Brandão et al. (2007) & $X$ \\
\hline Inhab $\leftrightarrow$ AgeH & & $\begin{array}{l}\text { Perz (2001), Moran et al. (2003), Brondizio } \\
\text { and Moran (2008) }\end{array}$ & $X$ \\
\hline Lpri $\leftrightarrow$ Hfert & & Sills and Caviglia-Harris (2008) & $X$ \\
\hline Lpri $\leftrightarrow$ Acces & & Sills and Caviglia-Harris (2008) & $X$ \\
\hline Lpri $\leftrightarrow$ Cred & & Sills and Caviglia-Harris (2008) & X \\
\hline DrySv $\leftrightarrow$ Hfert & & $\begin{array}{l}\text { Indirect indications: Hughes et al. (2002), } \\
\text { Aragão et al. (2007) }\end{array}$ & $\begin{array}{c}X \\
\text { (sensitivity } \\
\text { analysis and } \\
\text { scenarios) }\end{array}$ \\
\hline Acces $\leftrightarrow$ FoRes & No & Pedlowski et al. (2005) & $\begin{array}{c}X \\
\text { (sensitivity } \\
\text { analysis and } \\
\text { scenarios) }\end{array}$ \\
\hline
\end{tabular}


Table A.1. (Continued).

\begin{tabular}{|c|c|c|c|}
\hline Relationship & $\begin{array}{l}\text { Significant } \\
\text { correlation }\end{array}$ & Relationship cited by relevant literature & $\begin{array}{c}\text { Data-FCM } \\
\text { and } \\
\text { expert-FCM }\end{array}$ \\
\hline Infra $\leftrightarrow$ NewSet & & Soler et al. (2009) & $\begin{array}{c}X \\
\text { (sensitivity } \\
\text { analysis) }\end{array}$ \\
\hline CHerd $\leftrightarrow$ Inhab & No & Faminow (1997) & $\begin{array}{c}X \\
\text { (sensitivity } \\
\text { analysis) }\end{array}$ \\
\hline
\end{tabular}

Note: Agrop, agro-pasture expansion; DrySv, dry season severity; Lpri, land prices; Cred, subsidized credits; Hfert, high fertility; Acces, accessibility; Infra, infrastructure; Fire, fire spots; CHerd, cattle herd; FoRes, forest reserves; OldSet, old settlements; NewSet, new settlements; SptCol, spontaneous colonization; Incap, per capita income; Inhab, number of inhabitants; AgeH, age of householders. 